\title{
To be or not to be: reassessing the origins of portable art in the Cantabrian Region (Northern Spain)
}

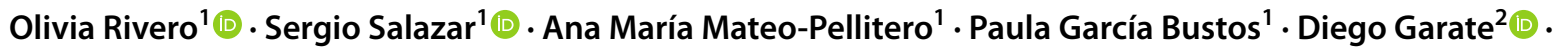 \\ Joseba Rios-Garaizar ${ }^{3}$
}

Received: 18 May 2021 / Accepted: 6 December 2021 / Published online: 29 December 2021

(c) The Author(s) 2021

\begin{abstract}
The characterization of the first portable artistic depictions in Cantabrian Spain is crucial for comprehension of the symbolic development of Neandertals and Homo sapiens in the context of the passage from the Middle to the Upper Paleolithic. However, despite the importance of these first graphic representations, their study has tended to lack the application of suitable methodologies to be able to discriminate between graphic activity and other kind of alterations (use-wear, taphonomic, or post-depositional). The present study has examined a significant sample of Middle and Upper Paleolithic lithic and osseous objects from Cantabrian Spain that have been cited as evidence of graphic activity in the literature. The contexts in which the objects were found have been considered, and the objects have been analyzed through the microscopic observation of the marks to distinguish between incisions, pecking, and engraving made for a non-functional purpose (graphic activity) and those generated by diverse functional actions or taphonomic processes (cutmarks, trampling, root marks, percussion scars, and use-wear). The results show that some regional Middle Paleolithic osseous objects display incisions that are neither functional nor taphonomic and whose characteristics are similar to graphic evidence attributed to Neandertals in Europe and the Near East. In turn, the first portable art produced by Homo sapiens in the Cantabrian Spain seems to be limited mostly to linear signs, and no figurative representation can be recognized until the Gravettian. This appears to indicate a particular idiosyncrasy of the region in the Early Upper Paleolithic, which, in comparison with other regions such as south-west France and the Swabian Jura, shows a later and less abundant production of portable art.
\end{abstract}

Keywords Portable art · Middle Paleolithic · Early Upper Paleolithic · Taphonomy · Microscopic analysis · Cantabrian Region

\section{Introduction}

The Middle to Upper Paleolithic passage has been one of the most debated issues in paleoanthropology in recent decades. Several debates converge in this time period, namely the cognitive and symbolic capacities of

Olivia Rivero

oliviariver@usal.es

Sergio Salazar

salazar.laredo@gmail.com

Ana María Mateo-Pellitero

anamatep00@usal.es

Paula García Bustos

pabulola@usal.es

Diego Garate

diego.garate@unican.es
Neandertals, the causes of their disappearance, the degree of complexity of Neandertal behavior in comparison with Homo sapiens, and the role of symbolic behavior in the success of Homo sapiens in colonizing the Eurasian continent (D'Errico and Stringer 2011; D'Errico et al. 1998). In the last few years, more evidence of the symbolic behavior

Joseba Rios-Garaizar jorios76@gmail.com

1 Dpto. Prehistoria, Historia Antigua y Arqueología, Universidad de Salamanca. C/ Cervantes S/N, 37002 Salamanca, Salamanca, Spain

2 Instituto Internacional de Investigaciones Prehistóricas de Cantabria (IIIPC), Universidad de Cantabria, 39005 Santander, Cantabria, Spain

3 Bizkaiko Arkeologi Museoa, Calzadas de Mallona 2, 48006 Bilbao, Bizkaia, Spain 
of Neandertals has been added: the first evident burials (Balzeau et al. 2020 and the references therein), the use of pigments and feathers for body decoration (Peresani et al. 2011; Finlayson et al. 2012; Rodríguez-Hidalgo et al. 2019; Soressi and D'Errico 2007), the production and use of ornaments (Caron et al. 2011 and the references therein) and portable art (Bednarik 2006; Majkić et al. 2017; Shaham et al. 2019), and recently the creation of parietal art (Rodríguez-vidal et al. 2014). This latter aspect has been the subject of an intense controversy, basically around the reliability of the used dating methods (see Pike et al. 2012; Bednarik 2012; García-Díez et al. 2013a; Pike et al. 2017; Pons-Branchu et al. 2014; Sauvet et al. 2017; Hoffmann et al. 2018a, b, c; Hoffmann et al. 2019; Aubert et al. 2018; Pearce and Bonneau 2018; Rodríguez-Vidal et al. 2014; Slimak et al. 2018; White et al. 2020). In contrast, the discussion about Early Upper Paleolithic art and ornament production has centered on the existence of regionally distinguishable artistic and decorative traditions, and also on the social role of the artistic explosion witnessed in the Aurignacian and onwards (Kulturpumpe) (Conard and Bolus 2003; Garate-Maidagan et al. 2015; Higham et al. 2012; White et al. 2012).

The Cantabrian Region in the Northern Iberian Peninsula has been one of the classic areas for the study of the MP and UP Paleolithic since the first rock art evidence was found in Altamira Cave in 1879 (Bahn 2016). This area has also participated in the debates about the original nature of the Châtelperronian, the possible interstratification of the Châtelperronian and the Aurignacian (in which El Pendo was one of the sites used to support this-now rejected-hypothesis) (Montes et al. 2005), or the existence of particular transitional industries such as the "Aurignacienne de Transition" defined in El Castillo (Cabrera et al. 2001), or the existence of a Mousterian refugium (see Higham et al. 2014; Marín-Arroyo et al. 2018; but see also Pinto and Grandal 2019). The data generated in the last few years have influenced these debates somewhat. Today there is a quasi-unanimous acceptance that the archaeological sequence in SW France (Mousterian, Châtelperronian, Protoaurignacian, Aurignacian, Gravettian) can be directly applied to the Cantabrian Region. Moreover, the new dates obtained from sites like Amalda I, Labeko Koba, Covalejos, and Aitzbitarte III suggest that there was almost no overlap between the Mousterian and the Châtelperronian, or between the Châtelperronian and the earliest Aurignacian (Marín-Arroyo et al. 2018). Additionally, the dates obtained from sites like Aitzbitarte III, La Viña, and Amalda I suggest an early development of the Gravettian in the region (Marín-Arroyo et al. 2018; Garate et al. 2020).

In parallel, different studies demonstrate the complex and historical nature of Neandertal societies in this region, with evidence of complex lithic technology management, bone and wood technology, broad spectrum subsistence strategies, landscape management, etc. (Gutiérrez-Zugasti et al. 2018; Gómez-Olivencia et al. 2018; Mozota Holgueras 2014; RiosGaraizar 2017; Rios-Garaizar and García-Moreno 2015; Rios-Garaizar et al. 2018; Sánchez-Romero et al. 2020).

Interestingly, graphic phenomena and ornaments have played a relevant role in these discussions. For example, the portable art objects from El Castillo Level 18 have been said to represent the first symbolic behavior in the Cantabrian Region (Cabrera et al. 2005), and the symbolic nature of some shell fragments located in Lezetxiki has been defended (Arrizabalaga et al. 2011). More recently it has been claimed that the decorated pebble from Axlor possessed a symbolic value (García-Díez et al. 2013b, but see Rios-Garaizar 2017) and a decorated bone from the same site has also been presented (Mozota Holgueras 2012). In addition, an age corresponding to the regional Middle Paleolithic has been attributed to a series of red dots in El Castillo, and a ideogram in La Pasiega (Pike et al. 2012; Hoffmann et al. 2018a), but there has been serious criticism of the reliability of the applied dating method (Pons-Branchu et al. 2014; Sauvet et al. 2017; Aubert et al. 2018; Pearce and Bonneau 2018; Slimak et al. 2018; White et al. 2020), and the debate about the authorship of this parietal art has not been settled.

Regarding the Aurignacian, few rock art sites have been attributed to this techno-cultural complex. Only the La Viña and El Conde linear incisions, with a superposition of archaeological levels, can be attributed unequivocally to the Aurignacian. Also, the Tito Bustillo anthropomorph gallery and Altxerri B are dated in the Aurignacian by their archaeological context. However, chronological precision is still lacking for the first rock art in the Cantabrian Region. The evidence of portable art and ornaments is also scarce and controversial. Most of the objects are affected by uncertain taphonomic processes and/or the anthropogenic nature of the incisions is questionable. In other cases, they are subject to vague chronological attributions (see GarateMaidagan et al. 2015).

Finally for the Gravettian, there is an increasing number of rock art sites, some secure portable art evidence, and more ornaments than in the Aurignacian (but still few if compared with neighboring sites such as Gatzarria, Brassempouy, or Isturitz). Interestingly, it has recently been proved that one of the best-preserved examples of ornaments, the necklace

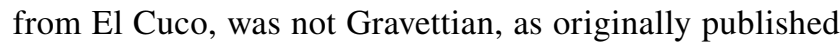
(Gutiérrez-Zugasti et al. 2013), but probably Aurignacian (Marín-Arroyo et al. 2018; Rasines et al. 2021).

In this context, the lack of systematic and detailed analysis of the putative portable art pieces from the regional Mousterian, Aurignacian, and Gravettian has hampered a correct evaluation of this phenomenon during the Middle to Upper Paleolithic passage. Some pieces come from very 
dubious contexts that need to be reconsidered; in others the symbolic nature has been incorrectly assessed; also, many pieces lacked a correct technological analysis and graphic presentation; and finally some pieces have been interpreted erroneously. The portable art record from the Cantabrian Region attributed to the Middle and Early Upper Paleolithic can play a relevant role in addressing such questions as the nature and meaning of Middle Paleolithic portable art, or the regionalization and social role of Early Upper Paleolithic portable art, but for this to happen, the available evidence must be systematically and critically revised, to attain a clearer view of this phenomenon.

Therefore, in this work, we propose a first-hand review of a very significant set of objects interpreted as decorated and traditionally attributed to the Middle Paleolithic, Aurignacian, and Gravettian in the Cantabrian Region. The main objective of the research is to approach, from an objective and critical perspective, the various ambiguities mentioned above and which impact on the understanding of the first Cantabrian portable art.

\section{Materials}

Twenty-eight of the 67 decorated objects that currently make up the inventory of the first regional portable art have been examined (see the Supplementary material for an updated inventory of decorated objects belonging to the Middle Paleolithic, Aurignacian, and Gravettian in Cantabrian Spain).

This sample is formed by artifacts from the sites of Morín, El Pendo, El Castillo, Hornos de la Peña, El Arco B, and La Garma A (Cantabria) and from Bolinkoba, Antoliñako Koba (Biscay), and Aitzbitarte III (Guipúzcoa) (Fig. 1). We have included two pieces of uncertain provenience (objects PE7 and AB1) because, owing to their characteristics and/ or context, they can be attributed to the first stages of the Upper Paleolithic.

We have chosen not to include ornaments in this study because they have been the object of several recent syntheses (Álvarez Fernández 2006; Gutiérrez-Zugasti et al. 2013), and because, while they are elements of symbolic expression (Vanhaeren and d'Errico 2005), they cannot be strictly defined as graphic activity. Also, we have not included some bone tools with marks because they can be interpreted as technological or functional traces, as for example the basal striations of Isturitz-type bone points (Rios-Garaizar and Garate 2014). Finally, some possible portable art pieces have not been directly analyzed, because they are not accessible (such as the engraved plaques from Covalejos, Sanguino González and Montes Barquín 2005), because they are missing (as in the case of some pieces from El Pendo and El Castillo, see supplementary material Table S4), or because they have been recently analyzed. This is the case of Aitzbitarte III Level Vb engraved slab (Garate and Rios-Garaizar 2011), the plaque from Labeko Koba Level VII (García-Díez and Arrizabalaga Valbuena 2000), the engraved hind from Antoliñako Koba Level Lmbk sup/smbk (Aguirre Ruiz De Gopegui and González Sainz 2011), and the marked pebble from Axlor Level VIII (García-Díez et al. 2013b).

The present study therefore includes three Mousterian objects, 12 Aurignacian, 16 Gravettian, and two objects without a precise stratigraphic attribution. They are listed in Table 1.

\section{Methods}

The artifacts have been examined with a consolidated methodology for the study of portable art based on microscopic analysis for the identification of the technical traces that indicate the operational chain of the production of the decorative motifs (D'Errico 1994; Fritz 1999; Rivero 2010, 2015). For the microscopic inspection we have used a Leica S8APO and MZ 16 binocular microscope, using an added-on Leica IC90E digital camera. This analysis has been completed with a taphonomic study based on the macroscopic and microscopic observation of the artifacts in order to identify the different alterations that might have affected the surface of the supposedly decorated objects and thereby discriminate between taphonomic traces, use-traces, and non-utilitarian and intentional modifications of the surfaces (Efremov 1940; Behrensmeyer and Kidwell 1985; Lyman 2010).

The microscopic analysis of the motifs and the taphonomic processes was complemented by the three-dimensional restitution of the engraved objects. In recent years, digital photogrammetry of close objects has developed considerably grace to the lower costs and greater accessibility of photographic equipment, and the development of dedicated software based on the SIFT or similar algorithms (González-Aguilera et al. 2009; Azéma et al. 2010; Feruglio et al. 2013; Richardson et al. 2013; Domingo et al. 2013; Grosman et al. 2014). Thus, close-range photogrammetry can currently be considered the standard methodology for recording rock art (Rivero et al. 2019), while $3 \mathrm{D}$ reproduction techniques have enabled analytical approaches, for example, in the field of traceology (Zotkina and Miklashevich 2016; Plisson and Zotkina 2015) and 3D analysis of cutmarks (Maté González et al. 2015, 2018; Yravedra et al. 2017; Courtenay et al. 2019).

In the present case, micro-photogrammetry has been applied to the engraved lines, using the images obtained with the Leica microscope, to generate precise metrical models. The images were processed with Agisoft Metashape Professional version 1.4.0 software. The analysis of the scaled 3D models allows not only the visualization of the cross-sections of the engraved 


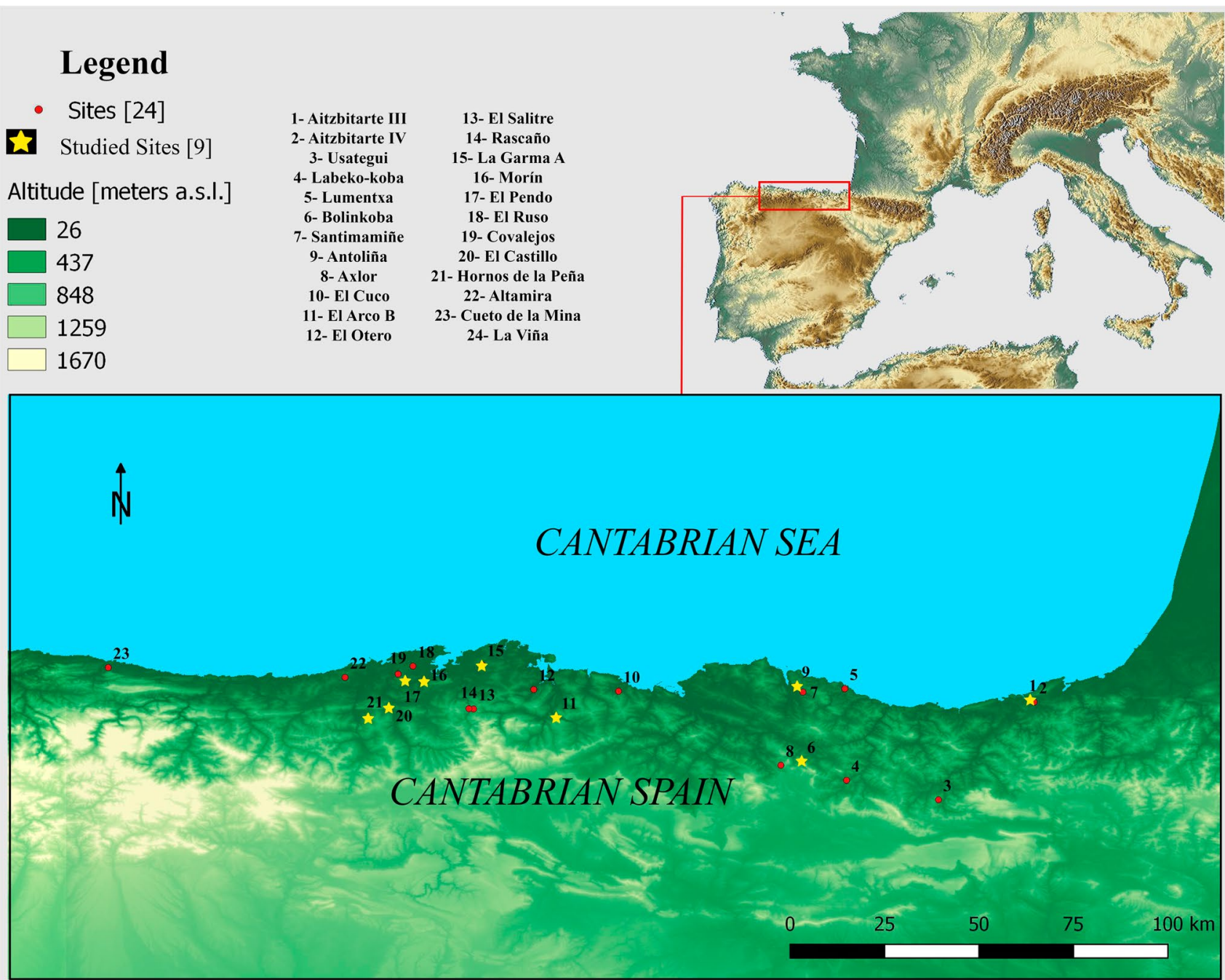

Fig. 1 Sites with remains attributed to the Middle and Early Upper Paleolithic in Cantabrian Spain. The sites studied here are marked by a star. Map by S. Salazar

grooves, but also to obtain basic measurements of the engraved lines such as the depth, breadth, and length.

The potential taphonomic nature of the traces has induced the development of a comparative methodology that can differentiate between engravings and other kinds of lines due to taphonomic causes. This methodology is based on the morphology of the grooves, analyzed by optical and electronic microscopy for the reference sample, and the characteristics of the profiles (width and depth) obtained from the microphotogrammetric models.

In this way, the analysis of the groove morphology is able to establish a series of criteria to discriminate engravings from taphonomic alterations, either anthropic or natural:

- The presence of internal striations (also known as barcodes; Fritz 1999) indicates that the line was made with a lithic tool. It can thus differentiate such a line from root marks on bone surfaces, as these possess a U-shaped profile and a rounded morphology at the start and end of the line, as well as leaving a reticulated pattern on the bone (Behrensmeyer 1978; Yravedra 2006; Moreno García 2013) (Fig. 2).

- The groove morphology differs depending on the type of tool, and therefore, this is evidence that can determine if a burin or a sharp edge was used. In the case of an engraving, it is normally wider and deeper at the start of the line, and it normally leaves stigmas at the start and end of the line (Fritz 1999; Rivero 2010, 2015), which indicates the use of a burin, whereas if the incision was caused during cutting, the line is usually wider and deeper in the middle, and it thins towards the ends. This morphology indicates the use of a sharp edge (Shipman 
Table 1 Mousterian and Early Upper Paleolithic artifacts from Cantabrian Spain and studied in the present paper

\begin{tabular}{|c|c|c|c|c|c|c|c|}
\hline Site & Code object & Media & $\begin{array}{l}\text { Dimensions (in } \\
\mathrm{cm} \text { ) }\end{array}$ & Level & Motif & References & Figure \\
\hline Antoliñako & AN1 & $\begin{array}{l}\text { Hammerstone/ } \\
\text { abrader }\end{array}$ & $5.40 \times 5.09$ & $\begin{array}{l}\text { Lmbksup-Smbk } \\
\text { level/Gravettian }\end{array}$ & Figurative: hind & $\begin{array}{l}\text { Aguirre Ruiz De } \\
\text { Gopegui and } \\
\text { González Sainz } \\
\text { 2011: 43-61 }\end{array}$ & S6 \\
\hline Bolinkoba & BO1 & Rib & $8.8 \times 1.3 \times 0.5$ & VI or $\mathrm{F}$ & $\begin{array}{l}\text { Series of edge } \\
\text { marks }\end{array}$ & $\begin{array}{l}\text { Barandiarán } \\
\text { Maestu 1972: } \\
\text { BO3 }\end{array}$ & S5 \\
\hline Bolinkoba & $\mathrm{BO} 2$ & Rib & $7.4 \times 1.2 \times 0.4$ & VI or $\mathrm{F}$ & $\begin{array}{l}\text { Series of edge } \\
\text { marks }\end{array}$ & $\begin{array}{l}\text { Barandiarán } \\
\text { Maestu 1972: } \\
\text { BO1 }\end{array}$ & S5 \\
\hline Bolinkoba & $\mathrm{BO} 3$ & Rib & $4.5 \times 1.2 \times 0.3$ & VI or F & $\begin{array}{l}\text { Series of edge } \\
\text { marks }\end{array}$ & $\begin{array}{l}\text { Barandiarán } \\
\text { Maestu 1972: } \\
\text { BO2 }\end{array}$ & S5 \\
\hline Bolinkoba & $\mathrm{BO} 4$ & Rib & $3.3 \times 2 \times 0.3$ & VI or F & $\begin{array}{l}\text { Series of edge } \\
\text { marks }\end{array}$ & $\begin{array}{l}\text { Barandiarán } \\
\text { Maestu } 1972\end{array}$ & S5 \\
\hline Bolinkoba & BO5 & Rib & $3.7 \times 1.2 \times 0.8$ & VI or $\mathrm{F}$ & $\begin{array}{l}\text { Series of edge } \\
\text { marks }\end{array}$ & $\begin{array}{l}\text { Barandiarán } \\
\text { Maestu } 1972\end{array}$ & S5 \\
\hline Bolinkoba & BO6 & Bone tube & $7.9 \times 0.8$ & VI or $\mathrm{F}$ & $\begin{array}{l}\text { Series of edge } \\
\text { marks }\end{array}$ & $\begin{array}{l}\text { Barandiarán } \\
\text { Maestu } 1972\end{array}$ & \\
\hline Bolinkoba & BO7 & Isturitz-type point & $8.2 \times 2.2 \times 1$ & VI or $\mathrm{F}$ & $\begin{array}{l}\text { Series of edge } \\
\text { marks }\end{array}$ & $\begin{array}{l}\text { Barandiarán } \\
\text { Maestu 1972: } \\
\text { BO7 }\end{array}$ & \\
\hline El Arco B & $\mathrm{AB} 1$ & Pendant/gypsum? & $1.31 \times 4.46 \times 1.2$ & On the surface & $\begin{array}{l}\text { Series of edge } \\
\text { marks }(2 \text { series })\end{array}$ & $\begin{array}{l}\text { González Sainz } \\
\text { et al. } 2003\end{array}$ & S8 \\
\hline El Castillo & CS1 & Pebble/quartzite & $5.25 \times 4.15 \times 2.4$ & 20/Mousterian & 4 dots & $\begin{array}{l}\text { Cabrera et al. } \\
\text { 2005: 505-526, } \\
\text { Fig. } 4\end{array}$ & 5 \\
\hline El Castillo & $\mathrm{CS} 3$ & Bone/metapodial & $2 \times 10.11 \times 2.2$ & $\begin{array}{c}\text { 18c/transitional } \\
\text { Aurignacian }\end{array}$ & Incised marks & $\begin{array}{l}\text { Cabrera et al. } \\
\text { 2005: 505-526, } \\
\text { Fig. } 5 \text { b }\end{array}$ & S3 \\
\hline El Castillo & CS7 & $\begin{array}{l}\text { Quartzite pressure } \\
\text { tool }\end{array}$ & $13.14 \times 7 \times 1$ & 12/ Gravettian & Figurative: feline & $\begin{array}{l}\text { Barandiarán } \\
\text { Maestu 1972: } \\
\text { 106, lám. 35.2, } \\
\text { CS. } 1\end{array}$ & 15 \\
\hline El Castillo & $\mathrm{CS} 2$ & $\begin{array}{l}\text { Bone fragment/ } \\
\text { scapula }\end{array}$ & $3.83 \times 3.14$ & $\begin{array}{c}\text { 18c/transitional } \\
\text { Aurignacian }\end{array}$ & Figurative: head? & $\begin{array}{l}\text { Cabrera et al. } \\
\text { 2005: 505-526, } \\
\text { Fig. } 5 \mathrm{c}\end{array}$ & 10 \\
\hline El Castillo & CS4 & Splintered bone & $1.83 \times 2.40$ & $\begin{array}{c}\text { 18c/transitional } \\
\text { Aurignacian }\end{array}$ & $\begin{array}{l}\text { Incised marks/ } \\
\text { series? }\end{array}$ & $\begin{array}{l}\text { Cabrera et al. } \\
\text { 2005: 505-526, } \\
\text { Fig. 5a }\end{array}$ & 9 \\
\hline El Castillo & CS5 & $\begin{array}{l}\text { Sandstone pebble/ } \\
\text { polisher? }\end{array}$ & $5.08 \times 5.91$ & $\begin{array}{c}\text { 18b/transitional } \\
\text { Aurignacian }\end{array}$ & Incised marks & $\begin{array}{l}\text { Cabrera et al. } \\
\text { 2005: 505-526, } \\
\text { Fig. } 6 \mathrm{~b}\end{array}$ & 8 \\
\hline El Castillo & CS6 & Hyoid bone & $2.61 \times 2.25$ & $\begin{array}{c}\text { 18b/transitional } \\
\text { Aurignacian }\end{array}$ & $\begin{array}{l}\text { Figurative: limb } \\
\text { and belly? }\end{array}$ & $\begin{array}{l}\text { Cabrera et al. } \\
\text { 2005: 505-526, } \\
\text { Fig. } 6 \text { a }\end{array}$ & 11 \\
\hline El Pendo & PE1 & Pendant/talc & $2.29 \times 3.52 \times 1.67$ & VII/Aurignacian & $\begin{array}{l}\text { Simulated atro- } \\
\text { phied tooth }\end{array}$ & $\begin{array}{l}\text { Barandiarán } \\
\text { Maestu } \\
\text { 1980:152, } \\
\text { Fig. 75:10 }\end{array}$ & S4 \\
\hline El Pendo & PE3 & Sagaie or awl & $6.1 \times 2.3 \times 2.2$ & IV/Gravettian & $\begin{array}{l}\text { Longitudinal } \\
\text { groove }\end{array}$ & $\begin{array}{c}\text { Barandiarán Maestu } \\
\text { 1980: Fig. 78: } 66\end{array}$ & \\
\hline El Pendo & PE7 & $\begin{array}{l}\text { Pebble/pressure } \\
\text { tool -hammer- } \\
\text { stone }\end{array}$ & $5.62 \times 7.72 \times 7.21$ & Sector 3/disturbed & $\begin{array}{l}\text { Figurative: } \\
\text { indeterminate } \\
\text { quadruped }\end{array}$ & $\begin{array}{l}\text { Unpublished/ } \\
\text { Located in the } \\
\text { MUPAC }\end{array}$ & 17 \\
\hline
\end{tabular}


Table 1 (continued)

\begin{tabular}{|c|c|c|c|c|c|c|c|}
\hline Site & Code object & Media & $\begin{array}{l}\text { Dimensions (in } \\
\mathrm{cm})\end{array}$ & Level & Motif & References & Figure \\
\hline El Pendo & PE4 & Shaped rib & $0.85 \times 5 \times 0.7$ & VI/Aurignacian & Series of marks & $\begin{array}{l}\text { Barandiarán } \\
\text { Maestu 1980: } \\
\text { Fig. 76:50 }\end{array}$ & $\mathrm{S} 1$ \\
\hline Hornos de la Peña & HP1 & Frontal bone & $7.51 \times 8.96$ & D/Aurignacian? & Figurative: horse & $\begin{array}{l}\text { Barandiarán } \\
\text { Maestu } 1973\end{array}$ & 13 \\
\hline La Garma A & GA1 & $\begin{array}{l}\text { Bird bone/pen- } \\
\text { dant? }\end{array}$ & $0.43 \times 1.02$ & C/Aurignacian & Series of marks & $\begin{array}{l}\text { Arias Cabal and } \\
\text { Ontañón Peredo } \\
2004\end{array}$ & $\mathrm{~S} 2$ \\
\hline La Garma A & GA2 & $\begin{array}{l}\text { Pierced metacar- } \\
\text { pal/pressure } \\
\text { tool? }\end{array}$ & $3.28 \times 12 \times 2.21$ & F/Gravettian & $\begin{array}{l}\text { Series of marks( } 4 \\
\text { series) }\end{array}$ & $\begin{array}{l}\text { Arias Cabal and } \\
\text { Ontañón Peredo } \\
\text { 2004: } 218\end{array}$ & S7 \\
\hline Morin & MO1 & Bone/rib & $1.91 \times 4.4$ & 20/Mousterian & Incised marks & $\begin{array}{l}\text { González Echega- } \\
\text { ray and Freeman } \\
1978\end{array}$ & 3 \\
\hline Morín & MO3 & Bone/splinter & $1.45 \times 2.41$ & 5 Inf./Aurignacian & Incised marks & $\begin{array}{l}\text { Barandiarán } \\
\text { Maestu } 1973\end{array}$ & 6 \\
\hline Morín & MO5 & Indet.bone/awl? & $0.62 \times 2 \times 76$ & IV/Gravettian & Chevron marks (4) & $\begin{array}{l}\text { González Echega- } \\
\text { ray et al. 1971: } \\
\text { Fig. } 122, \text { n }^{\circ} .51\end{array}$ & 13 \\
\hline Morín & MO6 & Pressure tool & $3.33 \times 12.96$ & IV/Gravettian & $\begin{array}{l}\text { Figurative: anthro- } \\
\text { pomorph? }\end{array}$ & $\begin{array}{l}\text { González Echega- } \\
\text { ray et al. 1971: } \\
\text { Fig. } 123\end{array}$ & 15 \\
\hline Morín & MO2 & Bone & $2.91 \times 10.13$ & 17/Mousterian & Incised marks & $\begin{array}{l}\text { González Echega- } \\
\text { ray and Freeman } \\
1978\end{array}$ & 4 \\
\hline
\end{tabular}

and Rose 1983; Bello et al. 2009; De Juana et al. 2010; Maté González et al. 2015, 2018) (Fig. 3: a, b).

- The presence of the shoulder effect or barb effect (the latter at the end of the line) indicates cutmarks on bone as these are generally related to the use of retouched flakes (Domínguez-Rodrigo et al. 2009; De Juana et al. 2010; Galán and Domínguez-Rodrigo 2013) (Fig. 3: c, d). In contrast, intentional engravings do not generally leave striations adjacent to the main incision.

- The number of repetitions of the groove (Fritz 1999; Rivero 2015) is able to differentiate the intentionality of an engraving compared with other types of traces, such as cutmarks, as a groove deliberately deepened by successive incisions indicates intentionality rather than butchery marks. This criterion is directly related to the depth of the line and can lead to errors if comparing the marks left by cutting tendons which can be very deep after the bone has been defleshed. In this case, the criterion to differentiate the lines is the position, which will be on metapodials and phalanges in the case of removing tendons (Soulier and Costamagno 2017; Costamagno et al. 2019).

- Depth is another argument to differentiate between an engraving and cutmarks on bones or accidental lines on a lithic object. In a sequence of lines engraved with a single incision, they will tend to be of similar depth. In the case of cutmarks, the depths are variable owing to the existence of flesh on the bone surface (Costamagno et al. 2019).

- Additionally, other clearly recognizable taphonomic processes should be taken into account, such as trampling, which produces abrasion caused by friction between sediment and the object, either lithic or osseous (Fig. 4), weathering, and physical-chemical alterations that can also affect bone surfaces (Chaix and Méniel 2005; Yravedra 2006; Domínguez-Rodrigo et al. 2009; Abril López 2012; Fernández Jalvo et al. 2013; Moreno García 2013; Pineda et al. 2014; Mateo Pellitero 2015).

\section{Results}

The microscopic analysis of the artifacts presented below has resulted in interpretations that diverge from the data published previously (the total assemblage of analyzed artifacts is presented in the Supplementary Information). These divergences may refer to the interpretation of the engravings as symbolic motifs, the interpretation of the nature of 

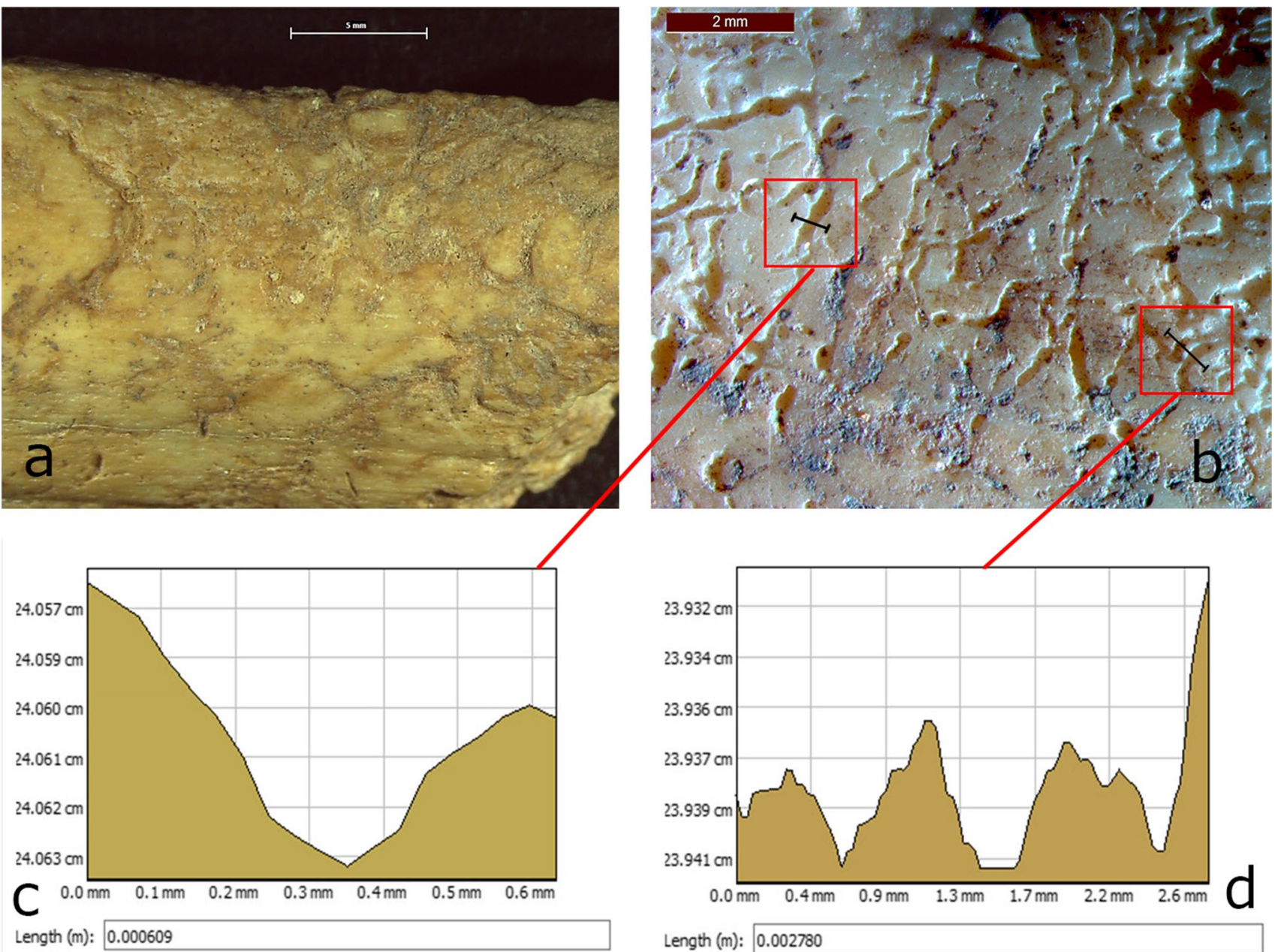

Fig. 2 Alterations to a bone surface caused by roots, showing the absence of barcodes, the U-shaped cross-section of the grooves, and their reticulated pattern. Photos: a by A. Mateo; b by O. Rivero

the decorated object (MO5), and the interpretation of the representation (CS7).

\section{Mousterian}

Three artifacts have been studied, from El Castillo (1) and Cueva Morín (2).

CS1: quartzite pebble, El Castillo Level 20. Described as a grey quartzite pebble with four aligned pecked dots at regular spaces and another pecked dot above them. These were interpreted as non-utilitarian intentional marks (Cabrera et al. 2005). A re-analysis of the object has revealed technological features that allow to interpret a fragment of a bipolar on-anvil core. It displays a cortical surface, with the pecked marks and two fracture planes with opposed negatives (with a counter-bulb), sinuous ridges, and reflected fractures typical of pebbles worked by bipolar on-anvil percussion.
Microscopic observation shows that the dots are all very similar and were made by successive impacts in the same place, creating a small depression. They display differing numbers of blows: there is one with three impacts, two with two impacts, and another two with only one blow (Fig. 5). The object is marked by other slighter impacts on the rest of the cortical surface. The four "aligned" impacts are very near to a point of impact that has produced one of the negatives on the flaking surface, so it is very likely that these marks should be associated with the process of reducing the quartzite pebble by bipolar on-anvil percussion.

MO1: rib fragment, Cueva Morín. This object was found in Level 22 in the deep test pit excavated in Squares Vc and $\mathrm{Vd}$ in 1968. This level is beneath the thick calcite layer (Level 21) which suggests that it is an old level, possibly before MIS5. The artifact was not mentioned in either the first or second monograph on the excavation and is first described in 1978 (González Echegaray 1988) as a "bone with a series of engraved lines in the style of the so-called 
Fig. 3 Criteria for the identification of engraved lines and/ or cutmarks. (a) Tear-shaped incision that is wider and deeper at the start of the line than at the end. (b) Cutmarks that are wider in the central part of the groove (after Shipman and Rose 1983). (c) and (d) Shoulder effect and barb effect produced by cutmarks. Image (c) corresponds to object CS4 studied below. Image (d) after De Juana et al. 2010. Photos: a and c by O. Rivero; $b$ and $d$ by A. Mateo
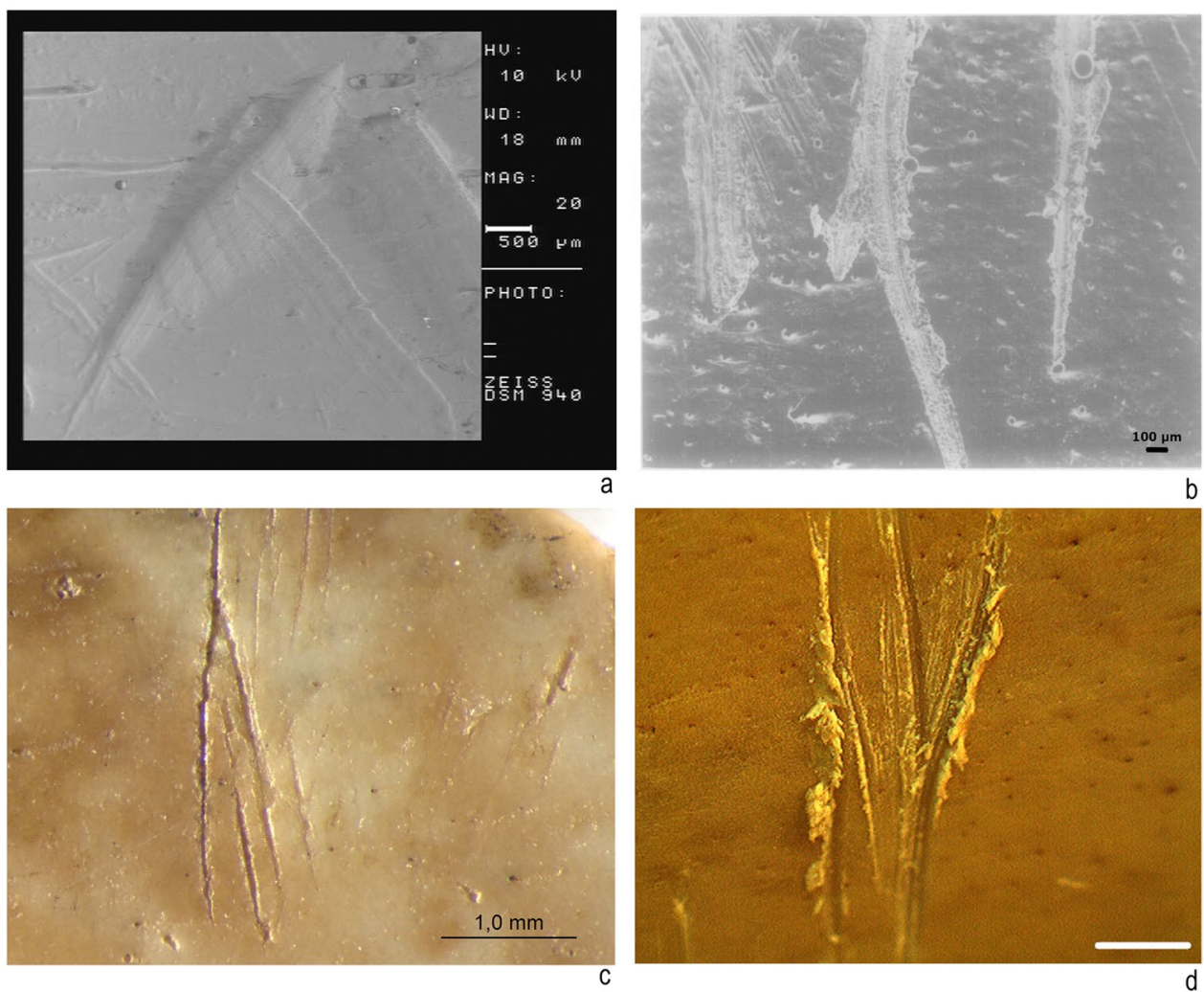

hunting marks and, as it is so exotic to the Mousterian world, we have never dared to assign it for certain to this level" (González Echegaray and Freeman 1978: 79).

It is a rib fragment about $4.5 \mathrm{~cm}$ long whose surface is affected by different taphonomic processes, especially weathering. Two groups of two parallel incisions appear on one of its faces. They are both of identical morphology, suggesting they were made with the same tool with the same kind of action. The fracture was possibly caused by another incision, which was enlarged by weathering, which caused cracks and exfoliation. According to Mozota Holgueras (2012) and Alcántara et al. (2006), fractures in dry bones are straight or stepped, with rough and irregular edges, and with the face of the fracture at right angles to the bone surface. The fracture of this bone corresponds to that description, and we can therefore conclude that it broke when it was dry, probably because of trampling or weathering.

The morphology of the marks suggests a main incision and a parasite striation, caused by a single action. Unfortunately, because of the deterioration of the bone surface, it is hard to determine if the incisions were caused by a cutting activity or were a decorative motif (Fig. 6). However, the regular width, depth, and direction of the marks suggest that the second option is the more plausible one.

MO2: bone fragment, Cueva Morín Level 17. This artifact has been described as a portable art object owing to the presence of five parallel incisions that end in a kind of "hook" (González Echegaray 1988) and which, according to this researcher "display a regularity that differentiates them from other marks caused unintentionally, and result from some intentional prehistoric human activity with decorative intent."

The observation of the bone shows that it is affected by numerous cutmarks all over its surface as well as remains of ochre. It is also affected by weathering and trampling, taphonomic processes that cause respectively exfoliation and cracks, and striations and scratches (Behrensmeyer 1978; Andrews and Whybrow 2005; Blasco et al. 2008; Domínguez-Rodrigo et al. 2009). Some of these stigmas may therefore be confused with cutmarks.

Microscopic observation of the series of incisions regarded as graphic evidence has shown that these were produced by two different actions. The operational chain indicates that all the long incisions were made first, and then the cuts, all made from top to bottom and with a similarly shaped tool (V-shaped cross-section, with the widest and deepest part of the incision in its central part). This sequence suggests that a series of cuts were made and these were later partially gone over again with a second series. Their parallel orientation may correspond to skinning (normally identified by deep parallel incisions) or filleting (Abril 2012; Egeland et al. 2014). A similar but shallower second series can be observed, made from bottom to top (with the bone in the same position as in the photograph) (Fig. 7). 

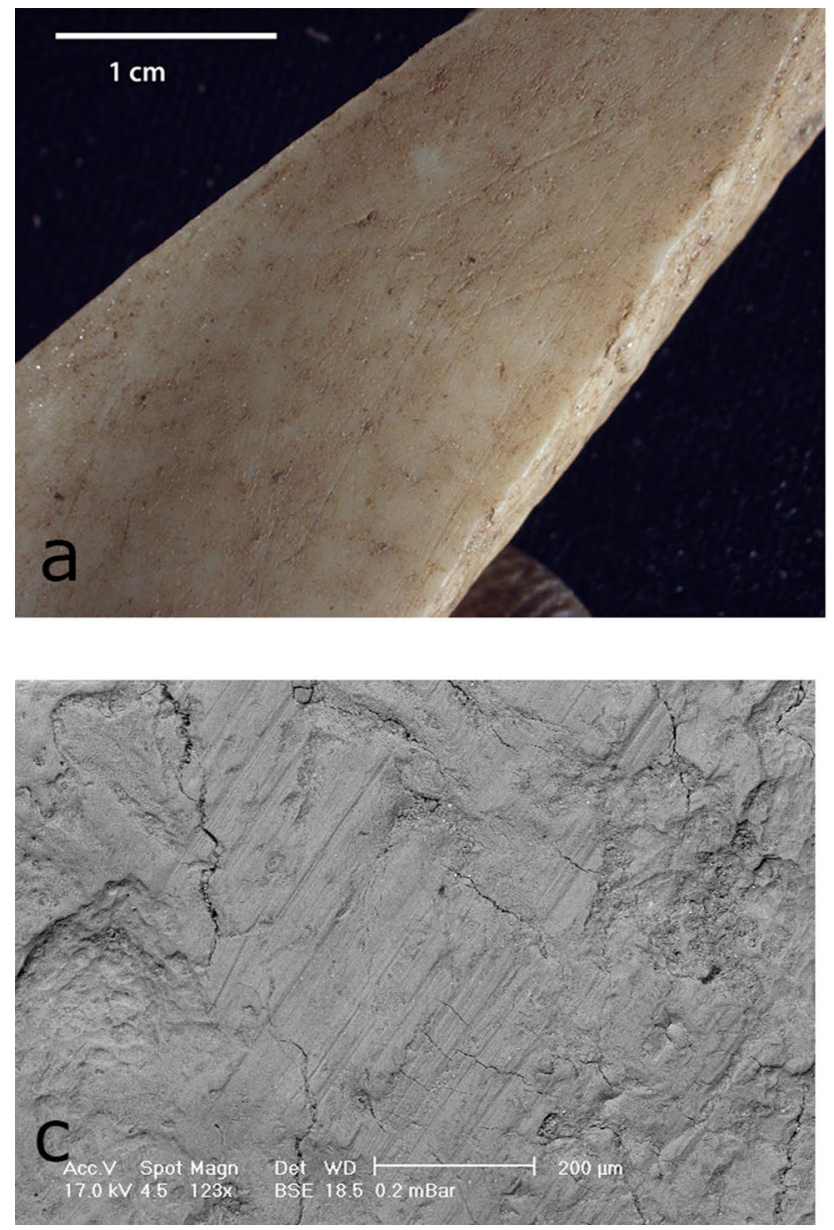

Fig. 4 Examples of alteration by trampling. (a) Macrophoto and (b) photomicrograph of marks on a bone surface caused by trampling. (c) SEM image of the same marks and (d) profile of the traces left

\section{Transitional Aurignacian}

CS5: sandstone pebble, El Castillo Level 18b. This object has been described as a sandstone plaque, shaped and engraved in the shape of a vulva (Cabrera et al. 2005: 505-526, Fig. 6b), although other authors express doubts about the symbolic nature of the incisions (Zilhâo and D'Errico 2003: 325).

The analysis of the object has determined that it is a triangular-shaped sandstone fragment with signs of being polished, probably because of a functional use as an abrader, grinder, or smoother (de Beaune 2000, 2017). It was given its present triangular shape by abrasion on all its surface and use-notches in the upper convex part. Several grooves on one of its faces are difficult to define. In the case of the upper incisions, their morphology suggests that they were made from right to left. The direction of the action cannot be determined in the other cases. The width and depth of the grooves are also unequal. The incision
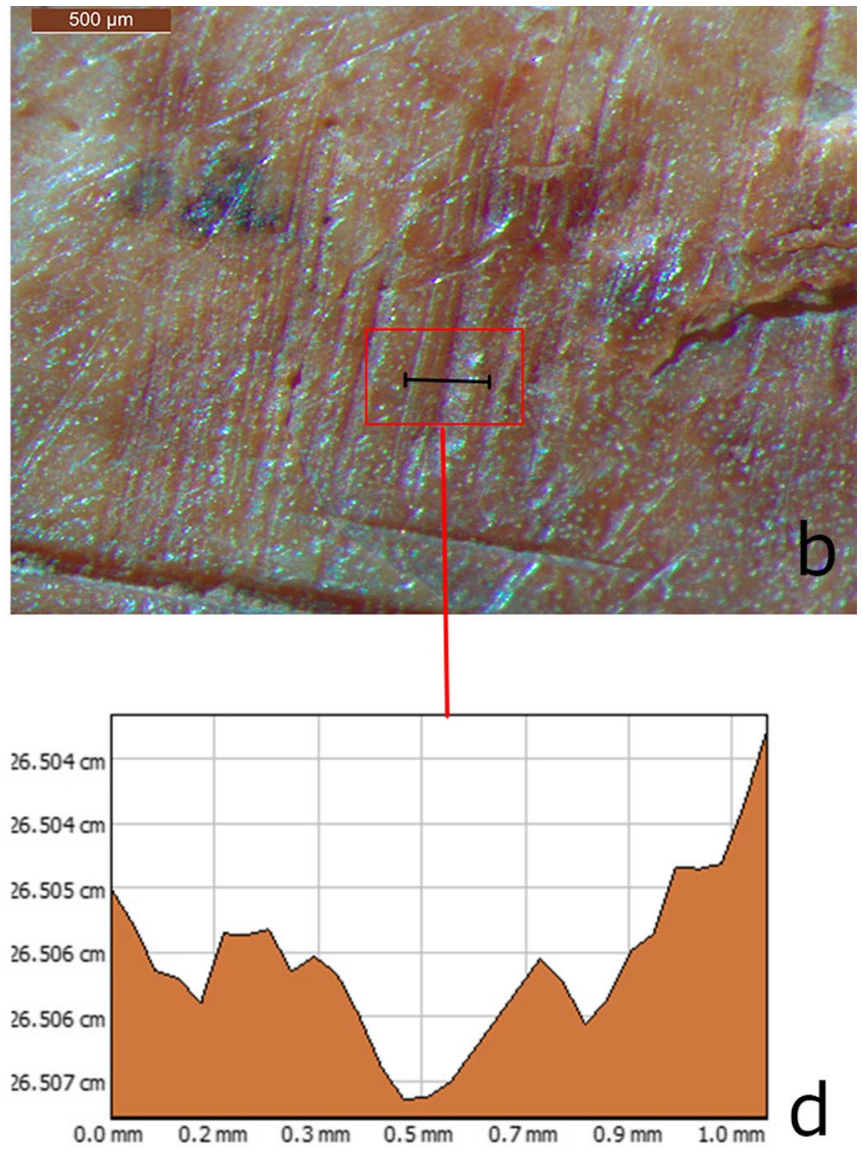

Length $(\mathrm{m}): 0.001112$

by trampling, characterized by a shallow depth and parallel grooves. Photos: a by A. M. Mateo and b, c, and d by O. Rivero

that supposedly marks the vulvar cleft was deepened by a second movement with the tool and is wider than the others.

There are no arguments supporting a decorative intention of the incision, but neither is there a functional explanation, as they are curved lines that can hardly be produced by a grinding action, as can be seen for example in needle polishers (de Beaune 2000, 2017).

Regarding its attribution as a portable art object, it can be stated that its triangular shape is intentional and there are no arguments in favor of considering it solely the product of a functional activity. In the case of the incisions, it similarly cannot be affirmed that they are the result of a functional action (Fig. 8).

CS4: chisel fragment, El Castillo Level 18c. Metapodial used as a chisel with three series of thin lines that have been described as evidence of graphic activity by Tejero and Bernaldo de Quirós (2007-2008) owing to their regularity. Nonetheless, the decorative nature of the marks has been 


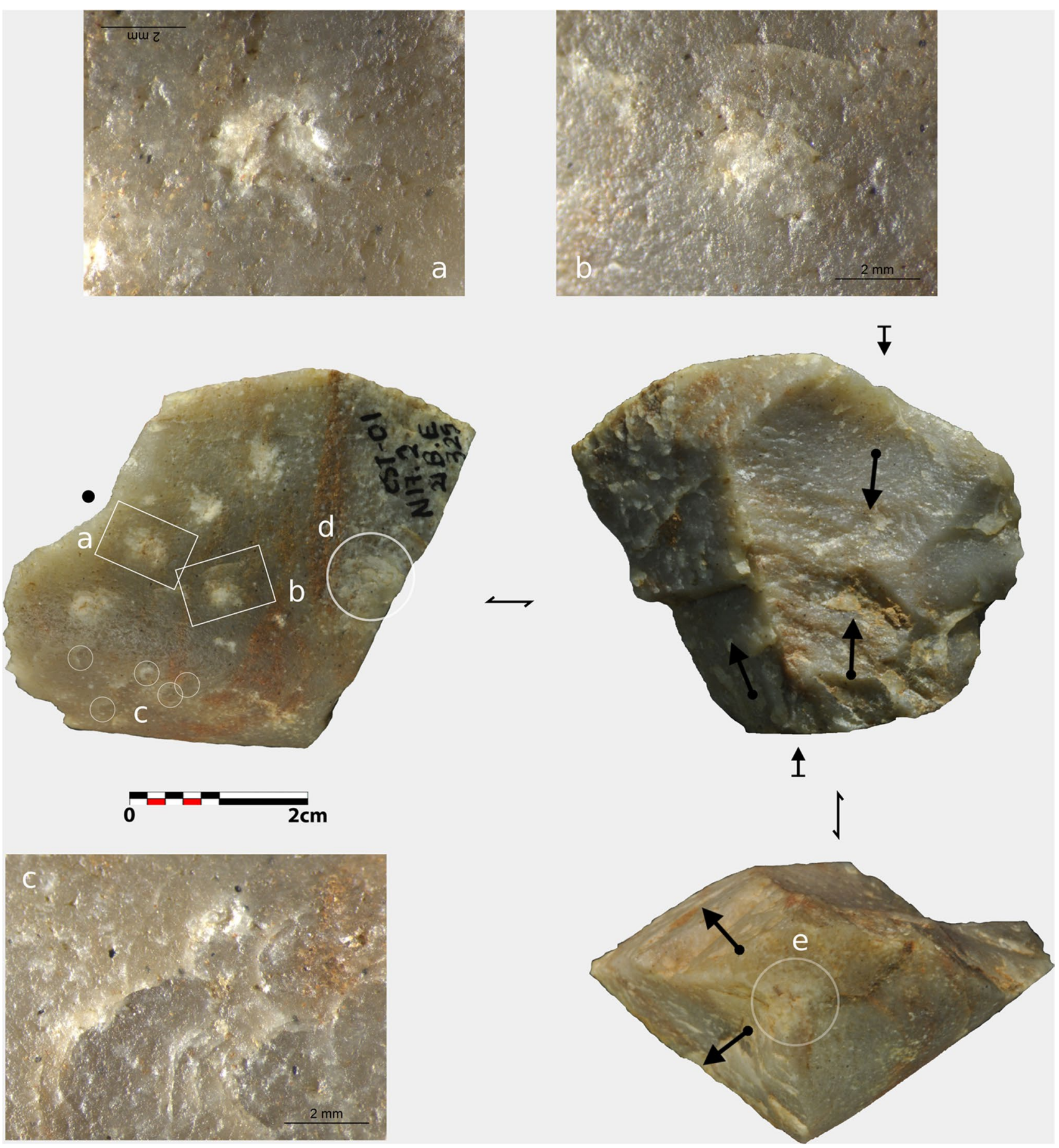

Fig. 5 El Castillo Level 20. Bipolar on-anvil quartzite core with percussion marks interpreted by Cabrera et al. (2005) as intentional symbolic marks. (a) Percussion mark with depression, (b) percussion

questioned by other scholars (Zilhâo and D'Errico 2003: 322), who state that these incisions were probably caused by filleting. mark, (c) battered surface with multiple incipient percussion cones, (d) battered surface, and (e) battered surface corresponding to contact with the hammer or anvil. Photos: O. Rivero
The observation of the object has shown that the incisions were caused by a single action and are shallow, with lateral parasite striations, accidents, and flaking around the edges of the incision. Their morphology resembles the shape 


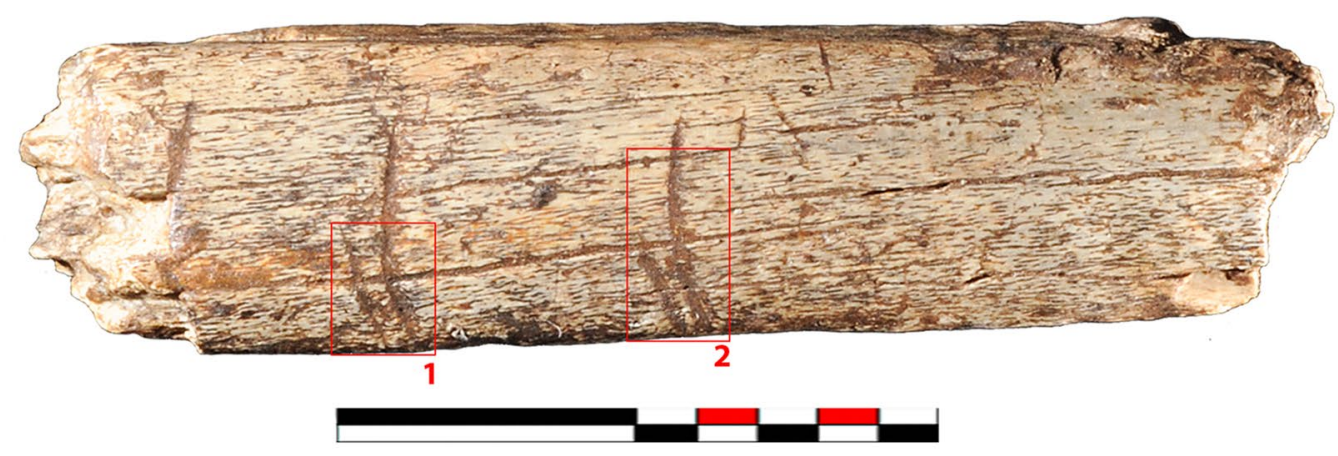

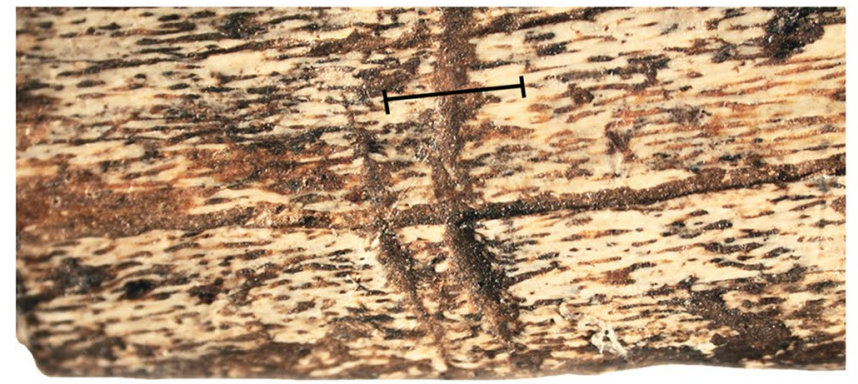

$10 x$

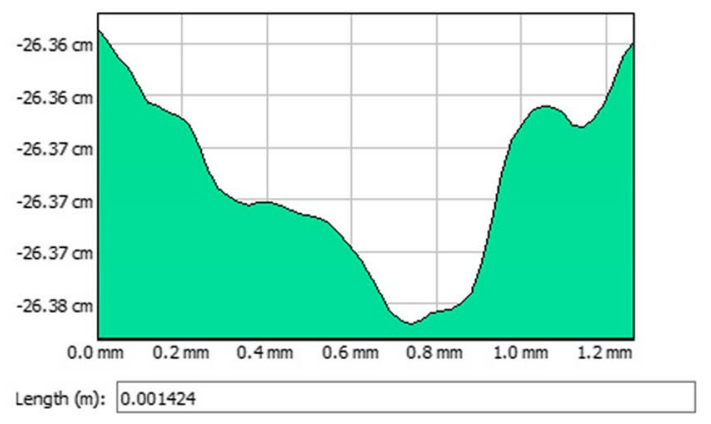

4

Fig. 6 Rib fragment from Cueva Morín in which the incisions of identical morphology and lateral parallel striations can be observed, as well as the deterioration of the bone surface. The profiles of the

of marks caused by butchery activity. In this respect, it is similar to the bone fragment from Morín attributed to the Aurignacian (MO3): the cutmarks resemble engraved lines with $\mathrm{V}$-shaped profiles and which are narrow at each end. The irregularities in the edge of the cutting tool and the action cause striations parallel to the marks. The fact that they are so close to one another might indicate the cutting of tendons or filleting, as has been previously suggested (Zilhâo and D'Errico 2003). The cutmarks are in a similar direction, towards the right and oblique, which is associated with a right-handed person (Abril 2012). The unequal depth of the incisions indicates that the object probably held remains of flesh when they were made. Similar marks have also been
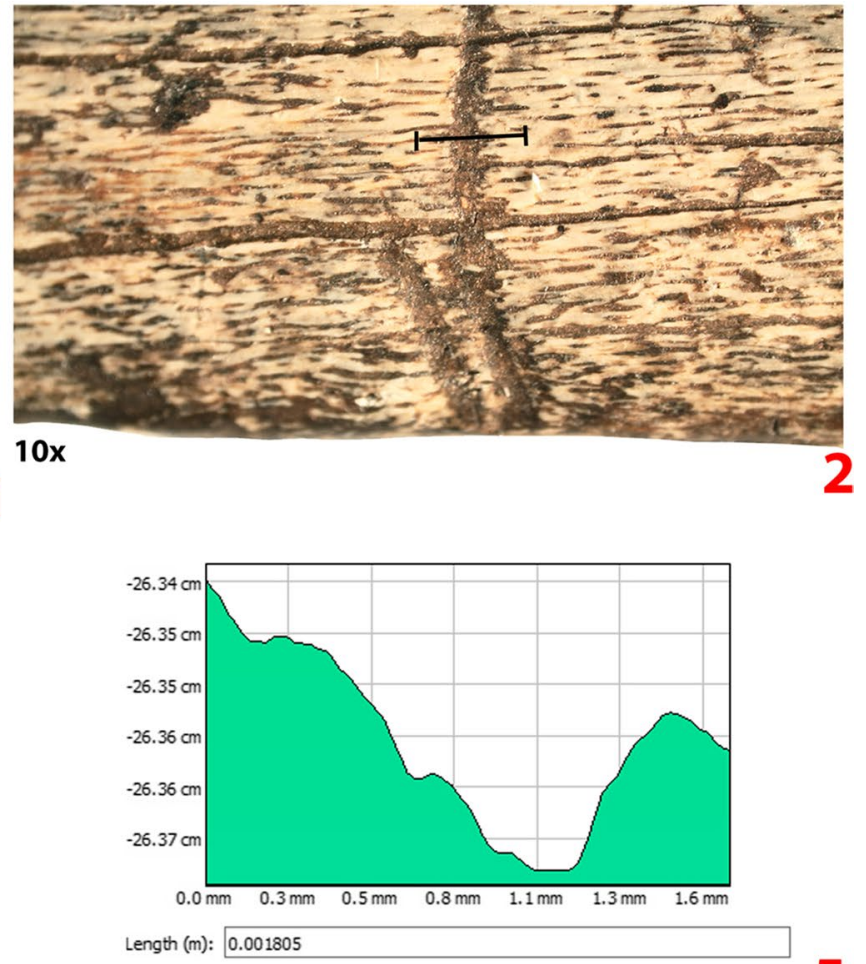

5

incisions (4 and 5) display an identical shape, suggesting a short incision sequence. Photos: O. Rivero

identified on the edges of other bones like this one, which supports the hypothesis that they are cutmarks (Fig. 9). In general terms, the object resembles a chisel found in Level $\mathrm{N}$ at Axlor, which displays similar marks, possibly caused by cutting tendons (Mozota Holgueras 2012, p. 170). The object also displays signs of surface scraping and polishing, probably connected with its use.

CS2: scapula fragment, El Castillo Level 18c. This is a scapula fragment with the depiction of an animal's head (Cabrera et al. 2005: 505-526, Fig. 5c). This front of the animal was drawn with graphite according to the first information that was published, although it was later said to be 


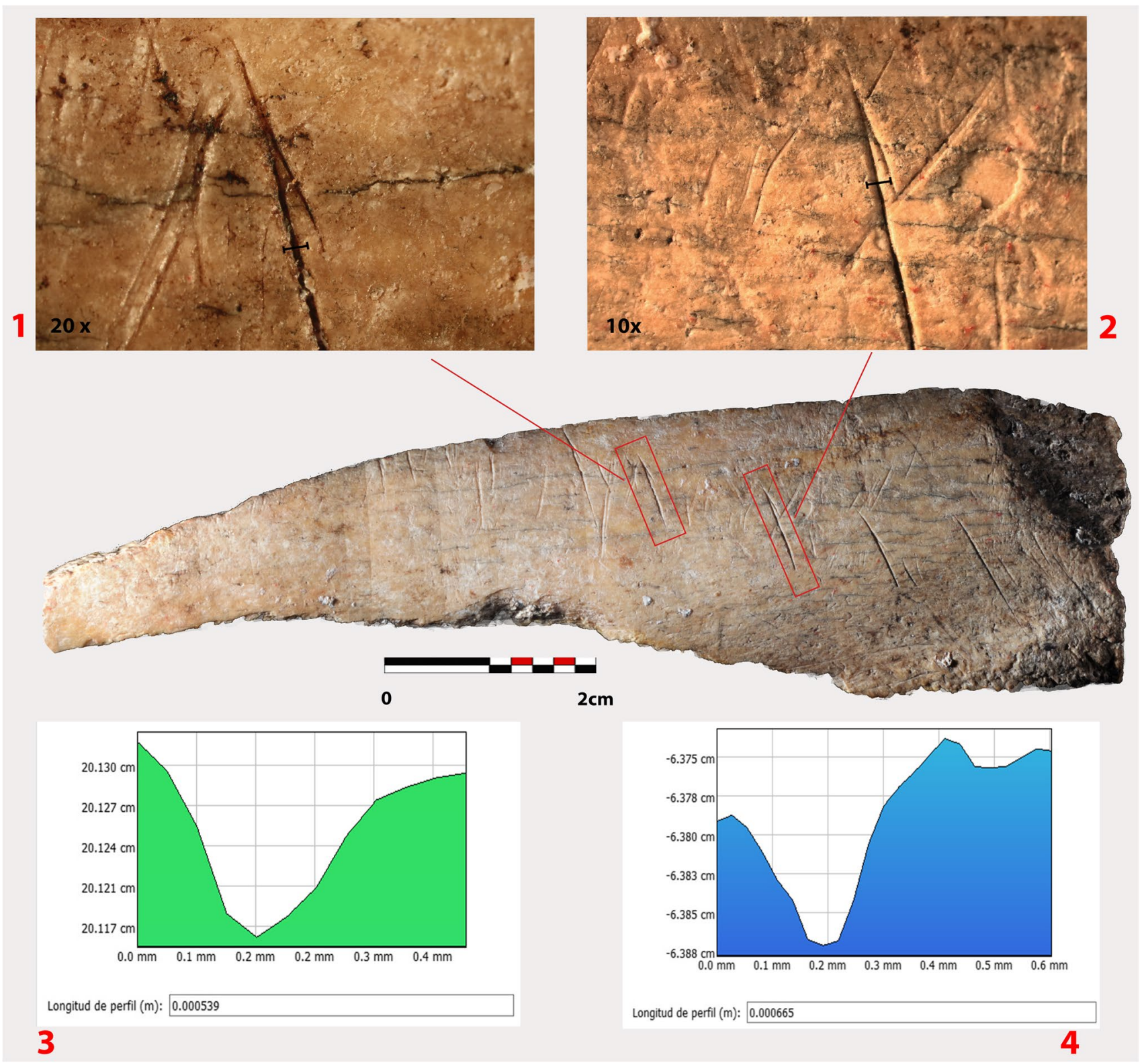

Fig. 7 Bone fragment from Cueva Morín. The marks of identical morphology were produced by two actions with the tool in two different sequences $(1,2)$. Their $\mathrm{V}$-shaped incisions are of identical

a pigment whose composition is still unknown (Tejero and Bernaldo de Quirós 2007-2008).

Despite its small size, the object displays numerous taphonomic alterations: root damage, weathering and trampling, and recent fractures. It is also affected by physical-chemical processes, namely precipitation of manganese. Weathering has affected mainly the upper face, flaking the bone surface and favoring fractures. This type of alteration is caused by exposure to atmospheric agents and can cause from flaking to the decomposition of the bone, leading to its fragmentation or disappearance (Behrensmeyer 1978; Mateo depth $(0.013 \mathrm{~cm})$. These may be explained as cutmarks made with a blade, which are widest in the central part of the line. Photos: O. Rivero

Pellitero 2015). Trampling is hardly perceptible on the upper face, whereas on the other side, it has left small grooves and fine shallow striations caused by friction with particles in the sediment, which can also favor fragmentation (Blasco et al. 2008; Domínguez-Rodrigo et al. 2009). The stains caused by precipitation of manganese are found on all surfaces of the object in the form of disperse dark marks. The presence of manganese oxide is associated with bacteria, which feed on the bone, and humid conditions (Fernández Jalvo et al. 2013). According to López-González et al. (2006), the appearance of this mineral on the bone surface is not regular, 
Fig. 8 Sandstone pebble from El Castillo (CS5). The photomicrographs show both the smoothing that affects both sides of the object $(1,3$, and $4)$, and marks of its shaping (3, notches in the concave upper edge, and 4 , thinning of the reverse side of the object) and a detail of the grooves (2). Photos: O. Rivero

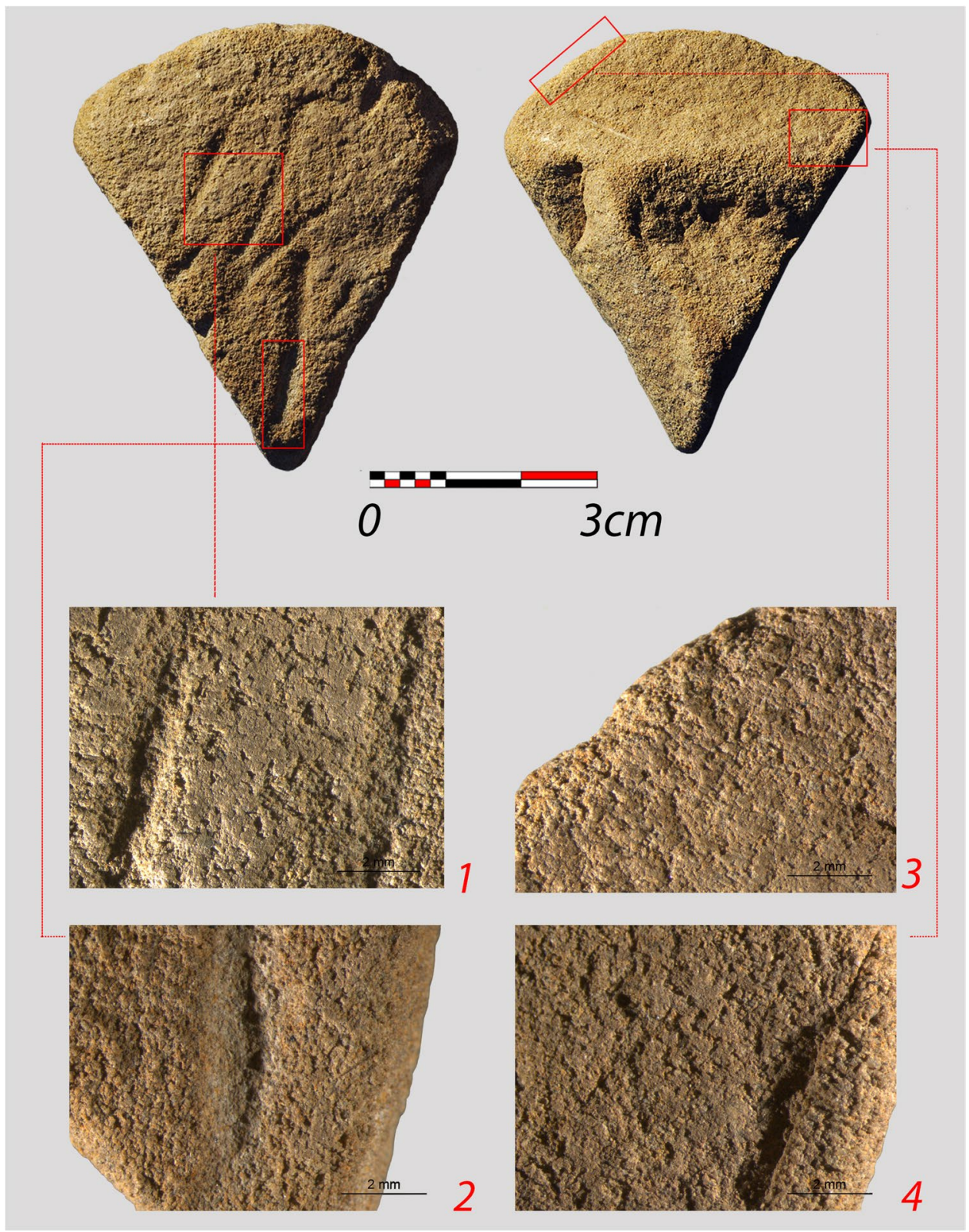

and the intensity of the color depends on the degree to which it is affected. In this case, this object closely resembles other bone remains affected by manganese oxide. Microscopic observations show that the supposed figure of an animal's head corresponds to stains which are probably also of manganese that has become fixed particularly intensely in those places where the bone surface is most altered, creating a false impression of a figurative depiction (Fig. 10).

CS6: hyoid bone fragment, El Castillo Level 18b. A limb and belly line of an indeterminate animal has been described on this hyoid fragment (Cabrera et al. 2005: 505-526, Fig. 6a). According to those researchers, it was drawn with a manganese "pencil" that created an engraving and fixed the pigment. Other scholars question the anthropic nature of the incisions, which they consider to be root marks, after the observation of photographs (Zilhâo and D'Errico 2003: 324-325).

The object displays numerous signs of taphonomic processes (root marks, precipitated manganese, etc.). It is also affected by trampling, which has left shallow striations over the whole surface. They are similar to the trampling marks identified by Cáceres et al. (2012), with similar curvature and width, as well as internal striations in the lines (Fig. 11). Similar marks are found on the bone surface, although they are less visible because they are shallower. The partial infilling of the marks with manganese has created the false impression of a drawn line. It should also be borne in mind that if they were painted lines, the brush or 


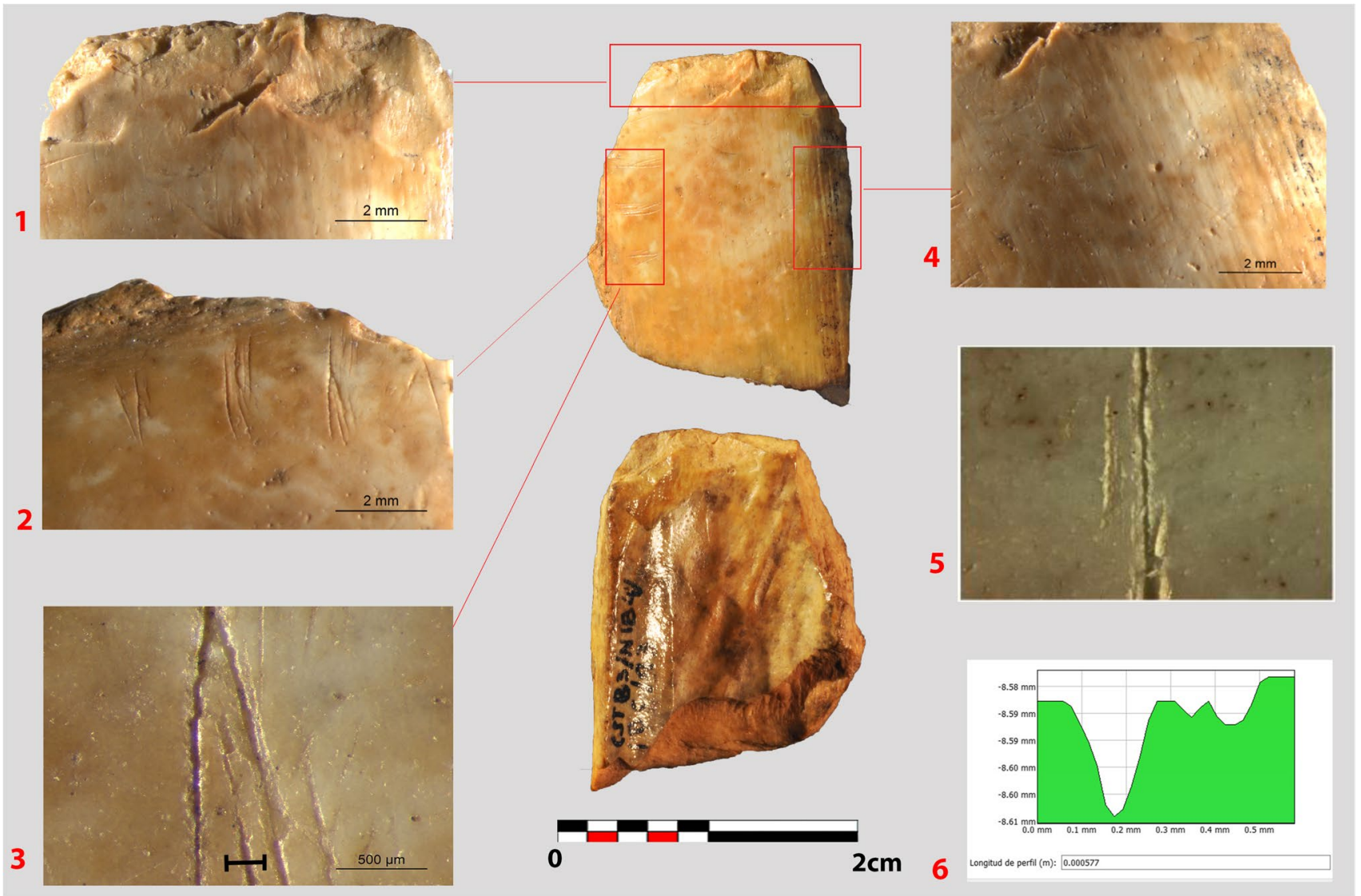

Fig. 9 Metapodial fragment used as a chisel from El Castillo. (1) Splintering of the distal part indicating its use as a chisel. (2) Series of incisions. ( 3 and 5) Details of the traces, which display a similar shape to cutmarks 5, after Costamagno et al. 2019. (4) Scraping of the bone surface. (6) Profile of the incision. The morphology of the lines can be explained as the barb effect caused by filleting. Photos: O. Rivero tool used would have been about $0.5 \mathrm{~mm}$ wide. The use of brushes or twiglets in Paleolithic art is very rare (Rivero 2017), and they are never so thin. The same is true of drawings using a manganese pencil, as this pigment usually needs to be broken up and dissolved (Chalmin 2003). It was equally unlikely to have been drawn with a manganese pencil, as remains of similar pigment are seen outside the groove caused by trampling.

The bone surface is also badly affected by roots, whose marks are characterized by variable length, width, and depth and are rounded with a U-shaped cross-section (Behrensmeyer 1978; Cáceres et al. 2012).

\section{Aurignacian}

MO3: bone splinter with marks, Cueva Morín Level 5 inf. This small piece of burnt bone displays a series of very fine marks with a V-shaped profile. It has been described by such researchers as S. Corchón (1986: 254) as a bone fragment with unsystematic incisions.
Observation of the bone shows that it is partially burnt. The clear difference in coloring may be because the bone was cooked without removing the flesh (Buikstra and Swegle 1989; Cain 2005; Yravedra 2006), although this cannot be demonstrated owing to the small size of the fragment. The blackened part would have been in direct contact with the fire, whereas the rest of the fragment remained intact because it was covered by meat. The morphology of the incisions is very similar, with lateral parasite striations. Their similarity to cutmarks on other objects is a determining factor; the marks display the same morphology, with greater depth in the central part of the incision. The position of the marks is also very similar, as well as the end of the line and its internal surface, which became narrower as the lithic tool advanced (Fig. 12).

HP1: decorated horse frontal bone, Hornos de la Peña. This frontal bone from a horse is decorated with an engraving of the hind-quarters of the same animal. It includes the limb, rump, and tail of the animal, as well as some lines forming a reticulated shape superimposed on the 


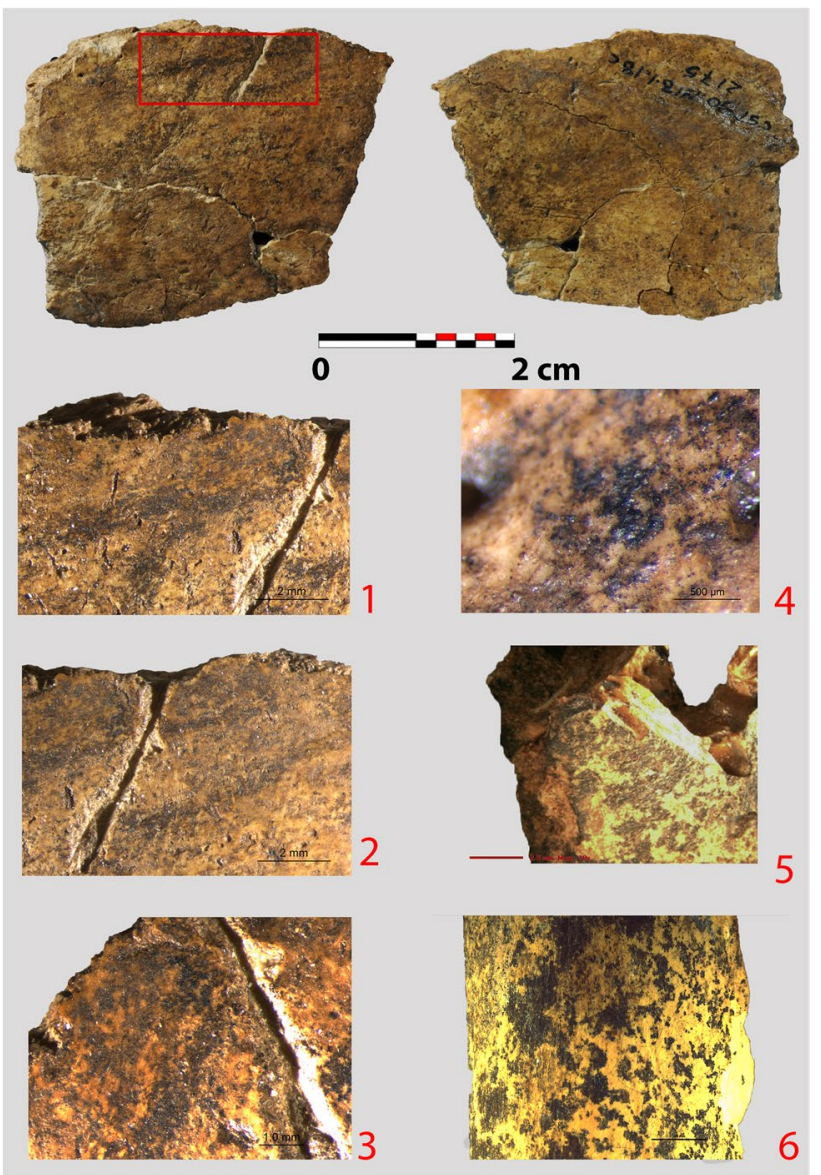

Fig. 10 Scapula fragment from El Castillo. As can be seen in the micrographs, the surface is badly affected by post-depositional processes $(1,2$, and 3$)$, and the manganese has fixed to the alteration of the bone (4), creating the false impression of a depiction. (5) Evidence of the impregnation of manganese on bone remains (after Marín-Arroyo et al. 2014). (6) Impregnation of manganese on a bone (after Mateo Pellitero 2015). Photos: O. Rivero

figure of the horse (Fig. 13). This is a controversial object as it is the oldest object with figurative art known in Cantabrian Spain (and therefore in the whole Iberian Peninsula). Problems in defining its chronological setting persisted until $\mathrm{H}$. Obermaier's excavation notes were found, as he indicates the provenience of the object in a drawing of the stratigraphic section (Tejero et al. 2008: 120). Nonetheless, new research in the section carried out by two of the present authors (OR and JRG) and the new study of the object have raised doubts about its cultural attribution. First, it has been determined that the definition of the sequence proposed by the early excavators was not fully correct as there are more archaeological levels than they thought and, based on the dates that have been obtained, the level considered by Obermaier as Aurignacian-Solutrean formed over a very long period and includes Gravettian levels that had not been documented until now (Rios-Garaizar et al. 2020).
Second, the analysis of the object from the technical and formal points of view shows that the object displays very deep incisions to draw the outline of the animal, and lines made with a single tool action, with a flat profile, for the internal fill of the figure. The formal analysis provides more data, as discontinuous marks were drawn for the internal line of the tail and a series of marks represent the hair at the end of the tail. These characteristics resemble motifs dated in the Middle Magdalenian, such as the bison engraved on a sperm whale tooth from Cueva de las Caldas (Rivero 2015) and a very similar representation engraved on a horse frontal bone from Isturitz (see Supplementary Information Figure S19).

\section{Gravettian}

A total of 26 portable art objects are known, of which 16 have been studied, including decorated bone tools.

MO5: fish bone, Cueva Morín Level IV. This object, catalogued as a decorated bone awl by Barandiarán Maestu (1972: 148) and by S. Corchón (1986: 254), is in reality a bone from a large fish, possibly a sturgeon. This object has not been worked but is the natural shape of the bone, which was probably used because of its pointed end. Its stratigraphic provenience is uncertain, although both the excavators (González Echegaray and Freeman 1971) and I. Barandiarán (1972) and S. Corchón (1986) in their respective catalogues of portable art attribute it to the Gravettian and Final Perigordian. The decoration consists of four angles and two convergent lines, located on the opposite end to the point. They are technically similar, formed by marks made by two cuts with the tool to deepen the groove and create a V- or U-shaped profile. However, the way of making the angles differs. In the one nearest the proximal end, the line on the right was made before the one on the left, whereas in the other three, the line on the right was made second. Finally, the two longer lines start at the proximal end and converge to form a larger angle than the other ones (Fig. 14). The regularity of the incisions and the construction of the angles suggest that these are not lines that respond to a functionality of the object.

CS7: pressure tool with figurative decoration, El Castillo Level 12. This pressure-flaking tool displays evidence of impacts and numerous lines on both faces. It was also engraved with a figurative motif that has usually been considered the depiction of a feline (Barandiarán Maestu 1972; Corchón 1986) although other authors have suggested that it is a bison (García-Díez and Ochoa 2012).

Despite the deficient conservation of the lines, as they were retraced with a pencil after it was excavated, it can be observed that the incisions were drawn with a single action with the tool, which has resulted in them being shallow and hard to see. The representation consists of a short, wide 
Fig. 11 Hyoid fragment from El Castillo. The bone surface is altered by roots (2) and trampling (1 and 2). (3) Profile of the grooves, which consist of shallow parallel lines. (4) Evidence of trampling (after Cáceres et al. 2012). The manganese has become fixed inside the grooves caused by trampling, giving the false impression of representing a painted motif (1). Remains on the whole bone surface and the nature of the grooves means that the possibility that this is a case of an engraved and painted motif can be discarded. (5) Evidence of trampling. (6) Profile of the groove, which displays the same characteristics as those on Object CS6. Photos: O. Rivero
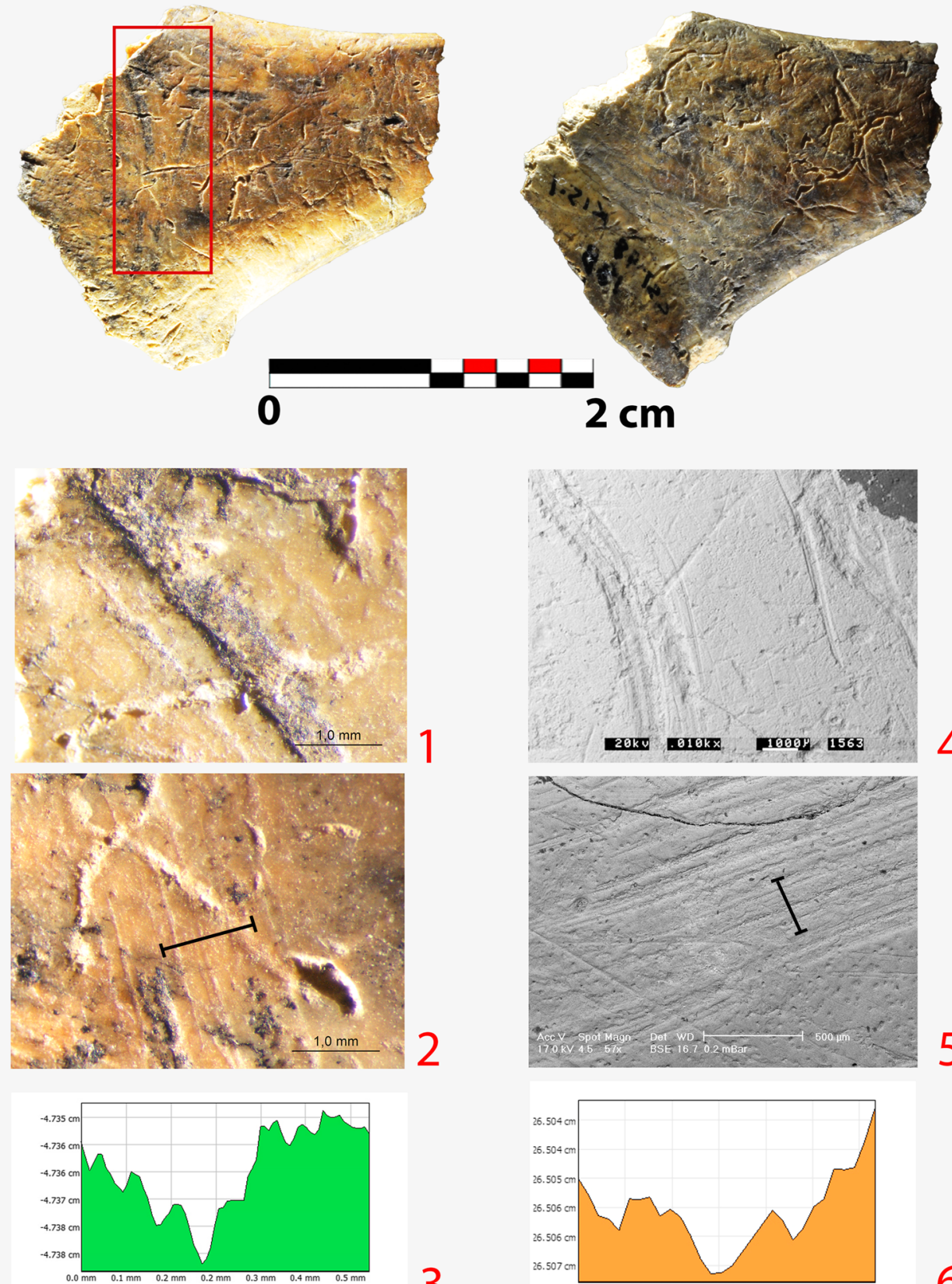

3

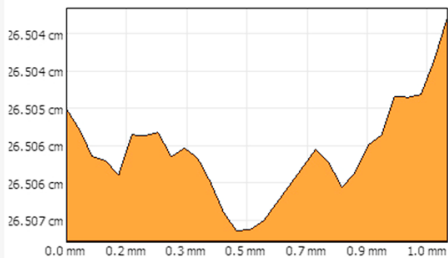

head, a cervical-dorsal line that emphasizes the withers and the lumbar depression, the belly line, and two lines that seem to represent a forelimb extended forwards. The shape of the figure, together with such details as the high withers and proportion between the belly line and cervical-dorsal line, means that it can undoubtedly be considered a feline and the interpretation as a bison can be discarded. Numerous engraved lines can be observed on the other face without forming an apparent motif (Fig. 15).

MO6: compressor with figurative decoration, Cueva Morín Level IV. Shale compressor with evidence of use on both faces, in the form of impacts and numerous marks. It has traditionally been thought to display the representation of an anthropomorph on one of its faces (Corchón 1986: 254). Microscopic analysis of the object reveals the abundance of lines of different kinds, some of which may amount to a human figure. However, the nature of the lines, made by a single action with the engraving tool and which do not join up to make a complete picture of the figure, together with their shallowness and fineness, suggest that the figure should be taken with precaution since it might be the fortuitous result of a series on involuntary incisions produced during the use of the object (Fig. 16). 


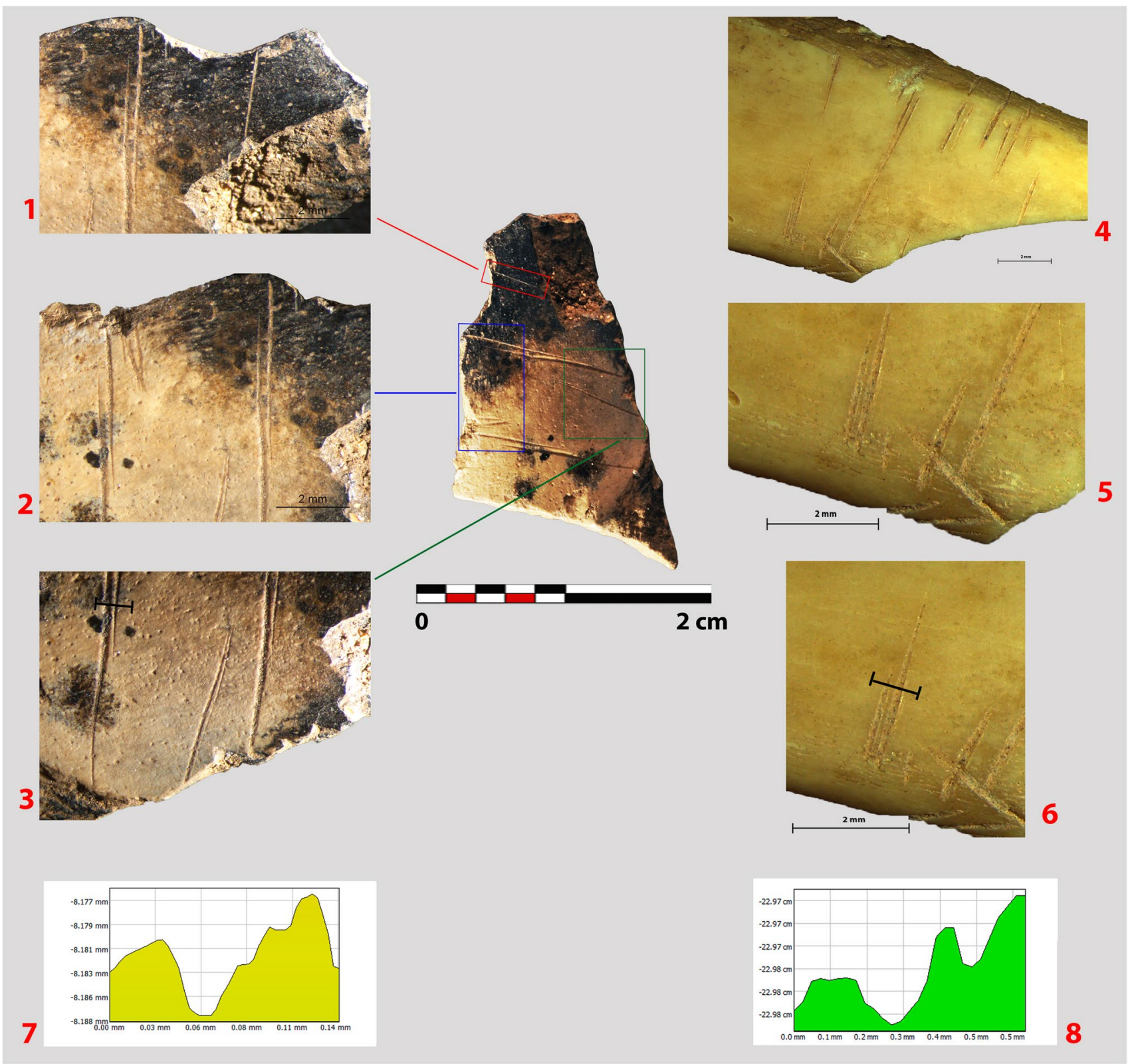

Fig. 12 Partially burnt bone splinter from Cueva Morín. The incisions were made with a single cutting action, display lateral striations, and are narrower at the ends of the line (1,2, and 3 ); a morphology that can be equated with cutmarks $(4,5$, and 6 , after Mateo
Pellitero 2015). (7) Profile of the incision, showing the shallow depth and V-shaped morphology, with lateral striations. (8) Profile of an incision with the same characteristics. Photos: O. Rivero

\section{Objects without an archaeological context}

PE7: engraved pebble with uncertain archaeological provenience, Cueva de El Pendo. Research in the MUPAC located an object from a disturbed level in Profile 3 in Cueva de El Pendo, found in J. Carballo's excavations. This is a lutite pebble used as a core and as a percussion tool, with six decorated faces, where the cortex was not removed by the extractions (Fig. 17). There are numerous lines in those areas, and some of them were probably caused by striking the pebble. Others are undoubtedly intentional, and parts of figurative representations can be appreciated. It can be 


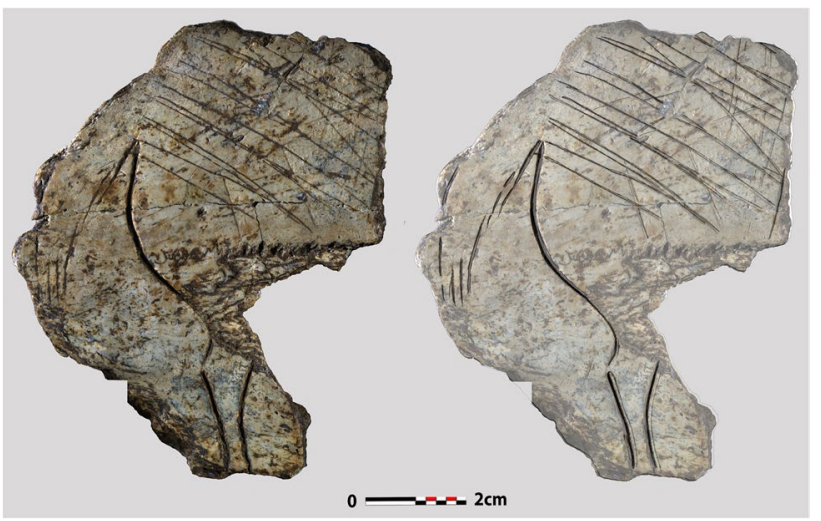

Fig. 13 Engraved frontal bone from Hornos de la Peña. Photo and tracing: O. Rivero

deduced that the pebble was fully engraved and then used, which destroyed part of the decoration.

From the technical point of view, the incisions were made with a single tool movement, which created fine, shallow lines. One of the representations, while only a partial figure, is characterized by a conventionalism observed in Gravettian depictions in the South of France. It is the lower half of an indeterminate animal, of which only the chest line, forelimbs, and belly line are preserved (Fig. 18). The particularity of the figure lies in the frontal perspective used to represent the limbs and the rectangular connection between them. This convention is seen in similar Gravettian representations at Isturitz and Gargas (Rivero and Garate 2014; Garate et al. 2020). These are also normally drawn on pebbles (see Supplementary Information Figure S10). The presence of this convention suggests an attribution based on formal criteria in the Gravettian.

\section{Discussion}

The Middle and Upper Paleolithic were key periods for the development of symbolic behavior among extant and extinct species (Homo sapiens, Neandertals, and Denisovans). The earliest documented evidence of such behavior is represented by portable art (decorated objects) and ornaments. Therefore, portable art is very important to understand the origin and function of the graphic expression of symbolic thought (d'Errico et al. 2001; Conard 2003; Zilhâo 2012; Henshilwood et al. 2018). The Cantabrian Region is one of the key places to investigate cultural developments in the Middle and Upper Paleolithic thanks to its important record of Neandertal and Homo sapiens sites (Mousterian, Châtelperronian, Aurignacian, and Gravettian), but intriguingly the portable art from these sites had never been studied in detail. As a result, there was a corpus of information that lacked a systematic analysis and description using updated methods.
Fig. 14 Awl made from a fish bone decorated with chevrons found in Cueva Morín. The natural point of the object can be appreciated (4) and the end where it can be observed that this is a fish bone (5). Photos: O. Rivero. Tracing: S. Salazar

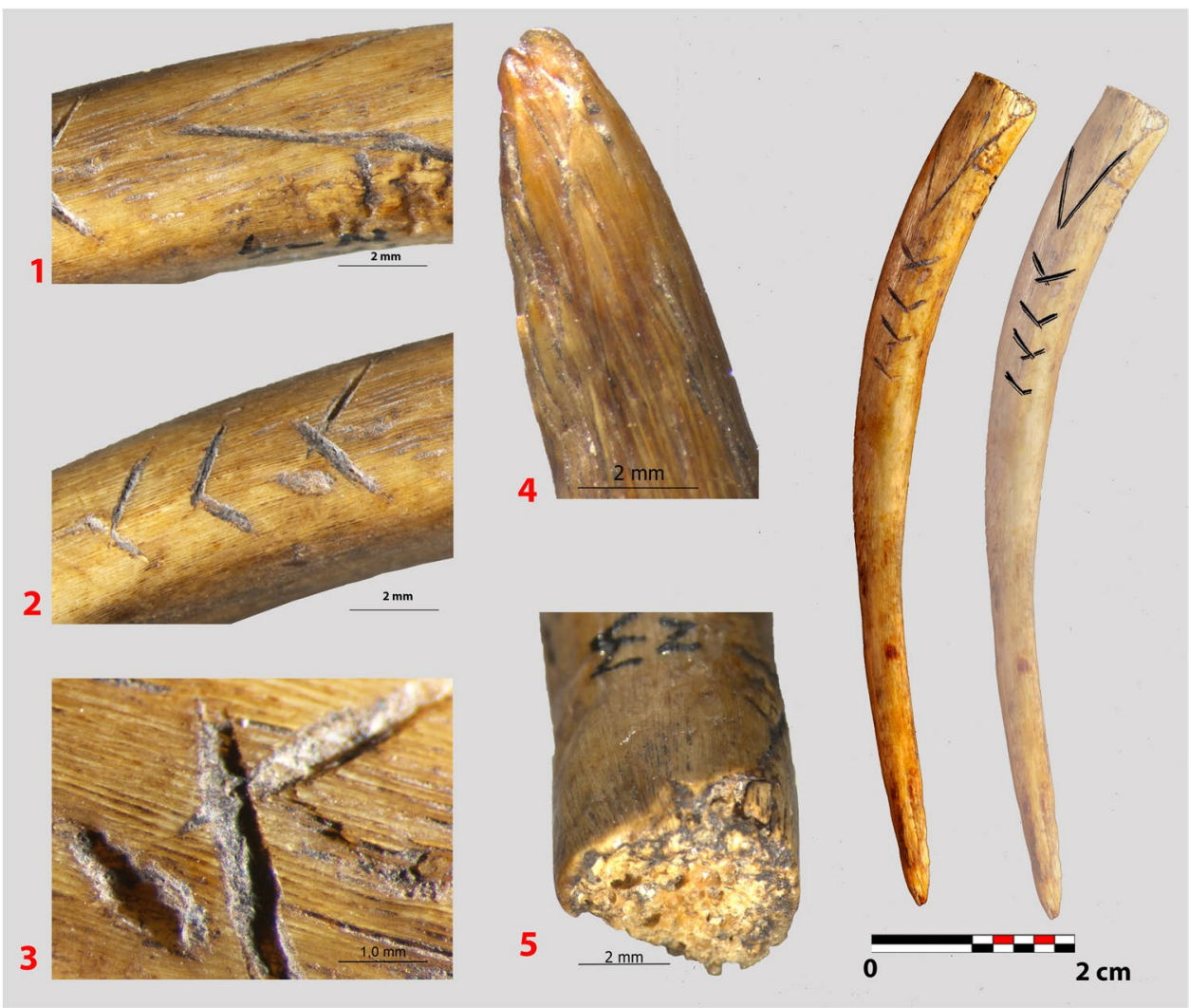


In this paper, we have tried to reassess some of the least well-known pieces and some of the more problematic and/ or controversial putative portable art objects from Middle Paleolithic, Aurignacian, and Gravettian sites in the Cantabrian Region.

Most of the pieces attributed to Neandertals, namely those corresponding to the Middle Paleolithic and Transitional Aurignacian (probably a particular variety of the Mousterian; Rios-Garaizar 2012), have been discarded as portable art after the re-analysis. This is the case of CS1, $\mathrm{CS} 2, \mathrm{CS} 4, \mathrm{CS} 6$, and MO2. In all these cases, diagenetic alterations, butchery marks, or technical traces have been misinterpreted by the original authors as intentional symbolic marks. This may also be the case of the marks on the pebble from Axlor Level VIII (García-Díez et al. 2013b), which probably have a functional explanation (see RiosGaraizar 2017). However, there is one artifact analyzed here (MO1), and one piece from Axlor Level N (Mozota Holgueras 2012), that could be interpreted as a decorated bone. The piece from Cueva Morín (MO1) was recovered in the deepest level of the sequence (Level 22) below several barren layers (18-21), which included a thick speleothem (Level 21). The level has never been dated, and the recovered material was too scarce to characterize it, but given its stratigraphic position and the fact that it was sealed by a speleothem (usually formed during interglacial periods: MIS5 or MIS7), it is quite likely that this level can be attributed to the regional Early Middle Paleolithic. The engraved bone was not identified or described in the first monographs (González Echegaray et al. 1971), but it was mentioned shortly after (González Echegaray and Freeman 1976). The authors described the marks as "hunting marks" but doubted that they were produced during the Middle Paleolithic, so they professed that they never dared to undoubtedly attribute this bone to Level 22. For this reason, the artifact was curated in the MUPAC under the label of "unknown stratigraphic provenance." This naturally creates some doubts about the stratigraphic attribution of the remain, but after carefully reading the published monographs, we do not find any argument against considering this object as coming from Level 22 and therefore attribute it to Neandertals. In fact there are some similarities with the engraved bone from Axlor Level N, which was described by Mozota Holgueras (2012). It can also be compared with other osseous artifacts with organized marks that have been interpreted as graphic representations (d'Errico and Vanhaeren 1999; Zilhâo and D'Errico 2003), such as the bones engraved with parallel marks found at La Ferrassie (France) (Capitan and Peyrony 1921), Oldisleben (Germany) (Bednarik 2006), Temnata (Bulgaria) (Crémades et al. 1995), Bacho-Kiro (Kozlowski 1992), and Nesher Ramla (Israel) (Prévost et al. in press). In the same sense, object CS5 recovered in El Castillo Level 18b shows evidence of intentional shaping to create a triangular form and displays traces that cannot be interpreted as diagenetic or functional, and consequently this is probably another example of symbolic graphic expression. Considering all this, the evidence from the Cantabrian Region reinforces the idea that the Neandertals displayed a restricted graphic symbolic expression, consisting of non-figurative series of engravings, as seen in other regions (Pesturina Cave, Majkić et al. 2017 or Quneitra, Shaham et al. 2019, among others), and which can be equated with the few parietal engravings attributed to the Mousterian (Gorham's Cave, for example, Rodríguez-Vidal et al. 2014).

Regarding the Aurignacian, we have discarded as portable art the piece from Cueva Morín Level 5 (MO3), and we also harbor serious doubts about the attribution to the Aurignacian of the piece from Hornos de la Peña. Firstly, the way it is made and the graphic conventions used suggest that it could be [Middle] Magdalenian, and secondly the new excavations in the cave suggest that the level of provenience, Level II, comprises a complex sequence including several layers of difficult attribution, some of them dated to the Gravettian (Rios-Garaizar et al. 2020). Also, Unit 5, which appeared to be in the position of upper Level II, has been dated in the Middle Magdalenian and displays clear evidence of disturbance and admixture, creating some doubts about the context of the engraved piece. In consequence, the remaining evidence of Aurignacian portable art in the Cantabrian Region can be reduced to the engraved slabs from Covalejos (Sanguino González and Montes Barquín 2005), and the more dubious examples from Labeko Koba Level VII (García-Díez and Arrizabalaga Valbuena 2000) and the engraved slab from Aitzbitarte III Level Vb Central (Garate and Rios-Garaizar 2011).

Series of lines and compositions of incisions and notches are found in Aurignacian portable art in Europe (for example, at Isturitz, Normand 2007; Gargas, San Juan et al. 2007; and Trou Magrite, Lejeune 2007) also including the coloring of the objects (Abri Pataud, Chiotti et al. 2007). However, abundant figurative portable art objects and geometric signs (Dutkiewicz 2021, Dutkiewicz et al. 2018, 2020) have been documented at a number of Central European sites from the first moments of the period (Conard 2003; Broglio et al. 2006). In contrast, in parietal art, fewer cases are known and are particularly concentrated in the Dordogne (White et al. 2012), Ardèche (Chauvet, Quiles et al. 2016; Aldène, Ambert et al. 2005; and Baume-Latrone, Azéma et al. 2012), and Italy (Grotta di Fumane, Broglio and Dalmeri 2005, Broglio et al. 2007). Nonetheless, the low resolution of direct and indirect dating methods and the methodological issues for both U/Th and 14C AMS systems and their limited application to motifs potentially attributable to this period are factors that may be causing an underestimation of the parietal phenomenon. In the case of Cantabrian Spain, several indicators (archaeological contexts, parietal 

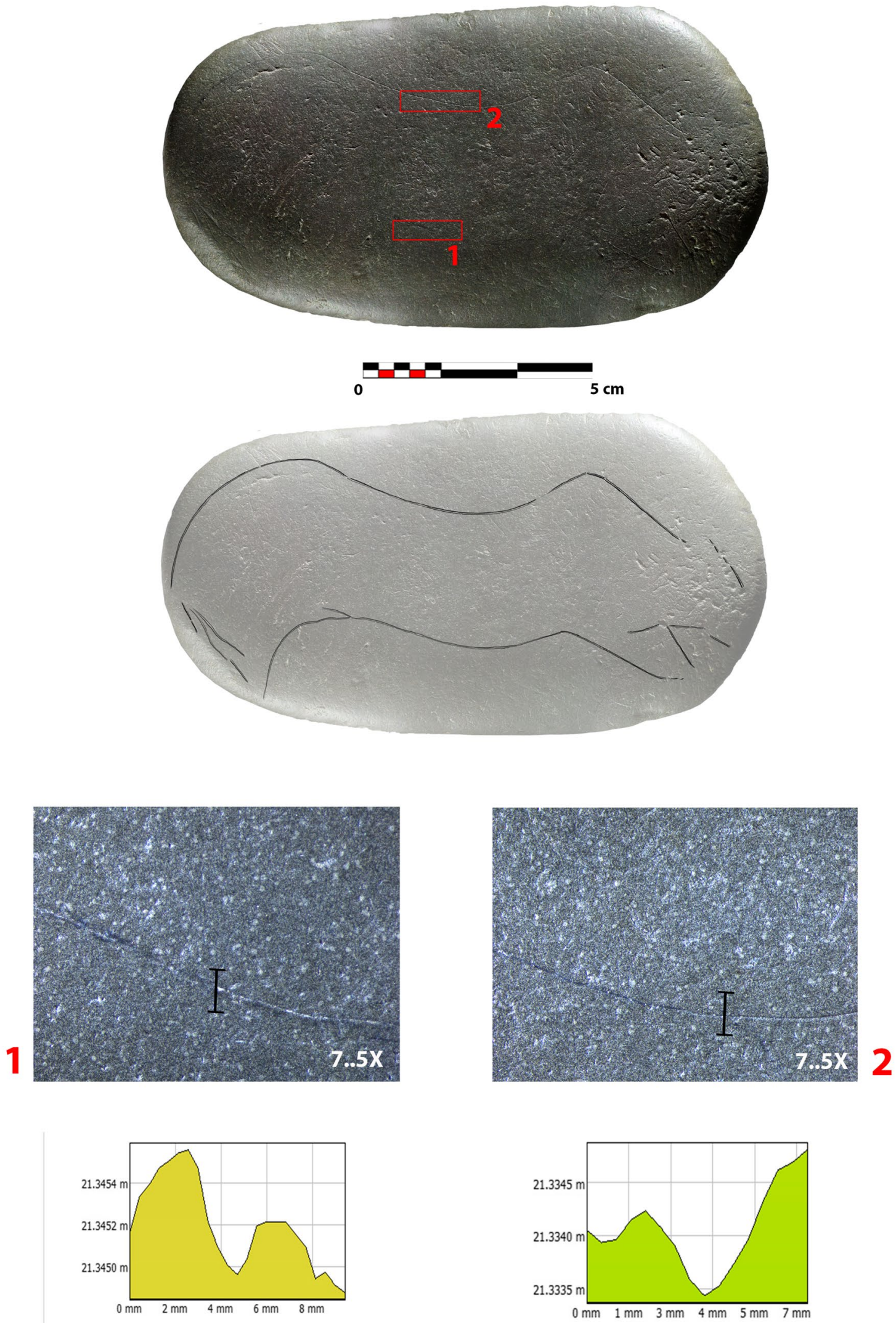

3

Longitud de perfil $(\mathrm{m}): 0.010044$

Longitud de perfil $(\mathrm{m}): 0.007623$ 
४Fig. 15 Pressure-flaking tool with figurative decoration from El Castillo. (1) Detail of the belly line. (2) Detail of the lumbar depression. (3) Profile of the belly line incision. (4) Profile of the lumbar depression incision. The shallowness of the line and its V-shaped profile can be appreciated in both cases. Photos and tracing: O. Rivero

stratigraphies, 14C AMS and U/Th dates, and stylistic comparison), when considered as a whole, support an Aurignacian phase for both figurative (at Tito Bustillo, Altxerri B, La Garma and Pondra) and non-figurative decoration (at La Viña and El Conde). Their importance would thus be significantly greater than the examples of portable art.

It is difficult to explain the absence of portable art in the Aurignacian sites from the Cantabrian Region. Despite numerous sites have yielded Aurignacian assemblages (Garate-Maidagan et al. 2015, Marín-Arroyo et al. 2018), very few pieces of indisputable portable art have been identified there. It is true also that there are few evidences of other symbolic expressions, such as ornaments, in those sites, and regarding the parietal art, there are some examples as we have mentioned above. In different works, it has been noted the existence of, at least, four very distinct traditions in the European Aurignacian art (Jura Swabia, Dordogne, SE France, and in northern Italy) (Ortega et al. 2015) and major differences in ornament production (White 2007); this suggests that there is not a unique symbolic expression during the Aurignacian, despite the similarities in other cultural products such as lithic or bone technology. Maybe, the absence of clear graphic manifestations in the Cantabrian Aurignacian is an expression of a particular symbolic behavior which left almost no traces in the archaeological record. However, some new findings, such as the recently published slabs from the Aurignacian levels of Covalejos cave (Montes Barquín and Sanguino González 2021), could change this interpretation in the future.

In the Gravettian, the situation is similar as regards utilitarian objects made from antler and bone, which are usually decorated with series of parallel incisions and notches, probably connected with the functionality of the artifacts.

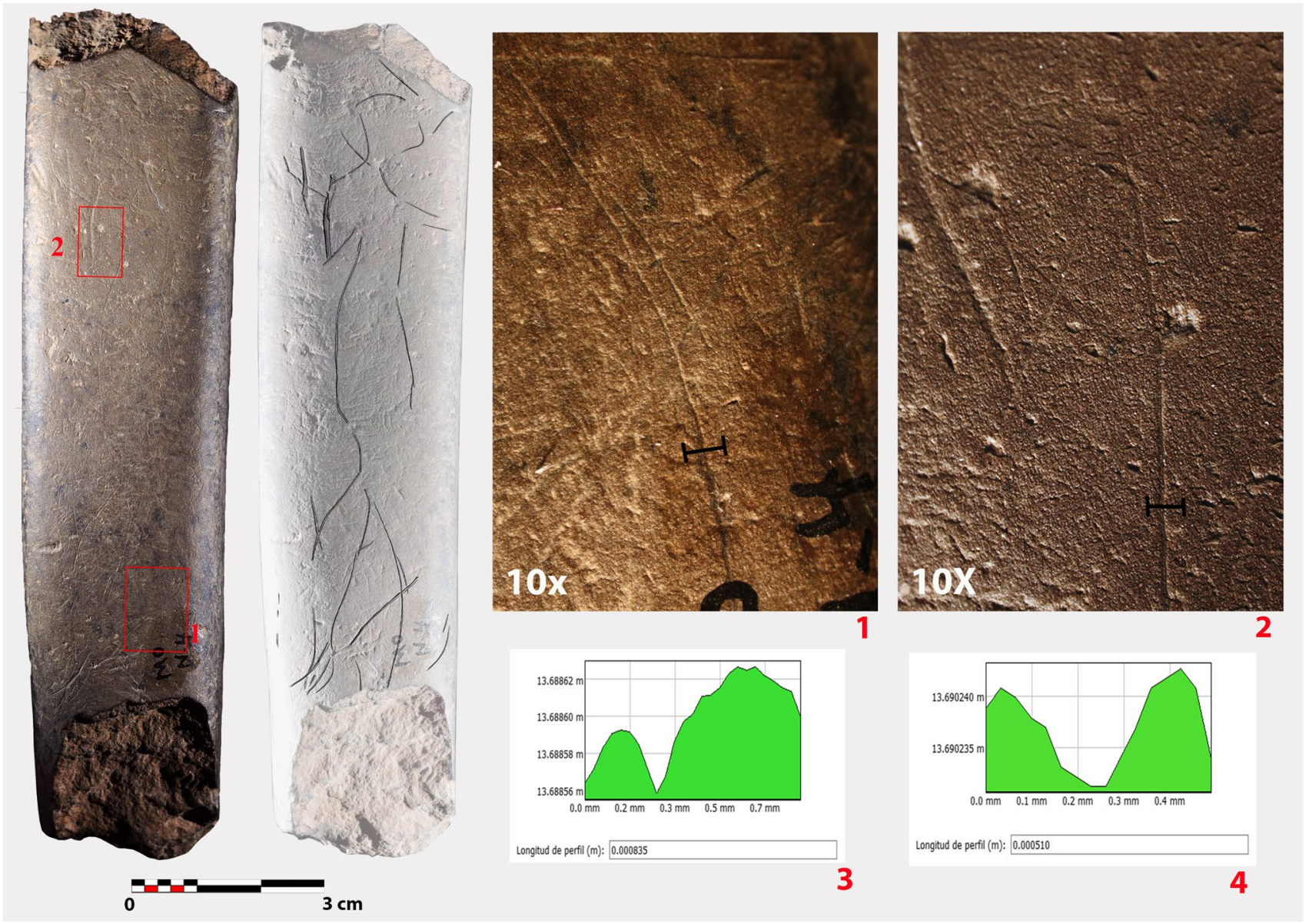

Fig. 16 Compressor from Cueva Morín. The object displays numerous lines, many of them parasites. Other shallow incisions made by a single cutting action (1 and 2) appear to form an anthropomorph fig- ure. However, the profiles of the incisions (3 and 4) reveal their varying cross-sections and depth. Photos and tracing: O. Rivero 

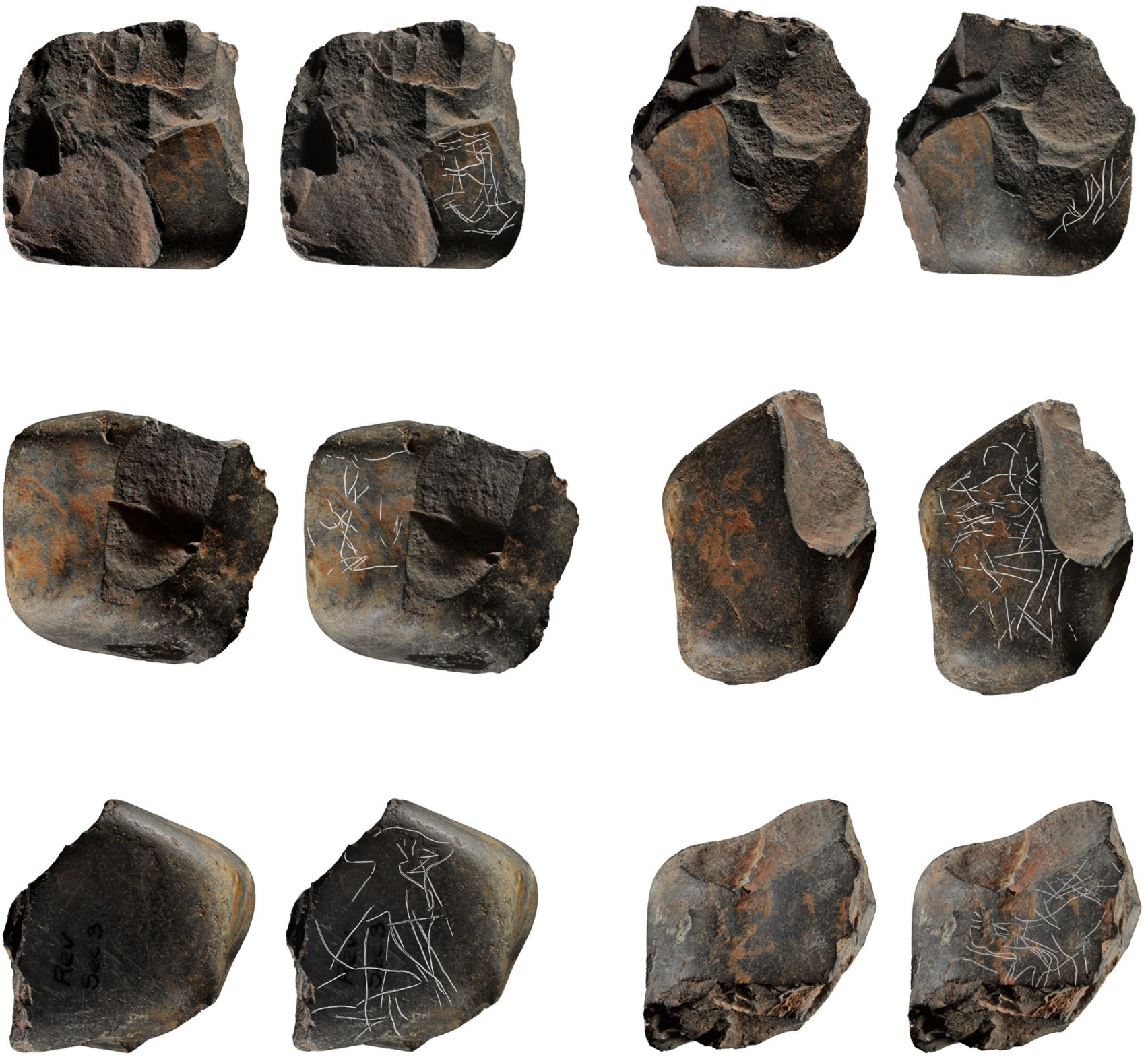

Fig. 17 Pebble from a disturbed level in Cueva de El Pendo, engraved and used as a core and hammerstone. It displays engravings on six faces, some of which are undoubtedly figurative. Photos and tracings: O. Rivero

In contrast, the first figurative representations appear on mineral objects, particularly the objects from Antoliñako Koba (Aguirre Ruiz De Gopegui and González Sainz 2011) and El Castillo (Barandiarán Maestu 1972), to which the pebble from El Pendo presented here may be added. These are utilitarian lithic objects with simple decoration, made with incisions involving a single tracing with the tool in most cases, which indicates that portable art in this period did not involve complex technical notions, as would occur in later periods (Rivero 2017). The subject matter of these depictions concurs with the first evidence of pre-Magdalenian figurative parietal art in the region. For the object from El Castillo, we can cite the felines at Altxerri B (González Sainz et al. 2013) and Tito Bustillo (Balbín-Behrmann et al. 2017). For the hind at Antoliñako Koba, resemblances with the dotted hind depictions have been noted (Aguirre Ruiz De Gopegui and González Sainz 2011). In the case of the pebble from El Pendo, as well as the portable parallelisms mentioned above, parietal examples are known at Aitzbitarte III (Garate et al. 2020), Alkerdi 2 (Garate et al. 2017), Cussac (Aujoulat et al. 2002), Gargas (Barrière 1976), and Cosquer (Clottes et al. 2005). 


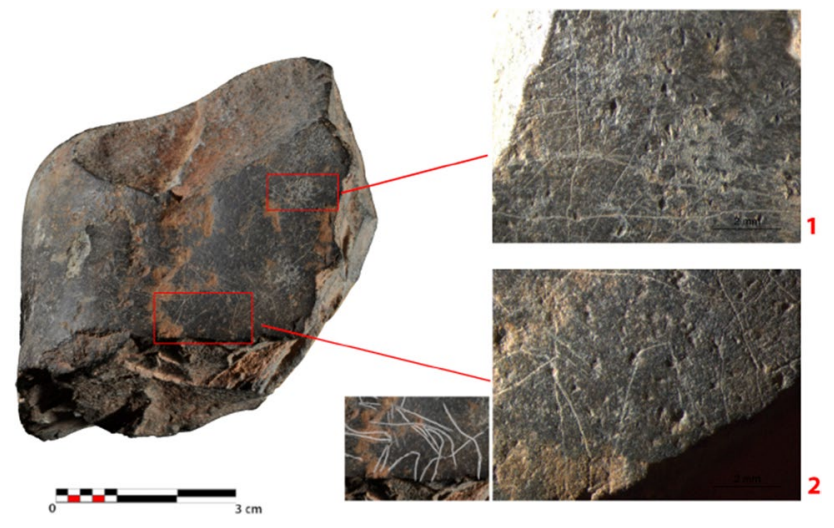

Fig. 18 One of the decorated faces of the pebble showing how it was used as a hammerstone (1) and a detail of a representation of an indeterminate quadruped, characterized by the frontal depiction of the forelimbs with a linear connection (2). Photos: O. Rivero

Figurative portable art became fully consolidated during the Gravettian, with a large concentration of sites in Central Europe (Svoboda 1997) and with a wide distribution of particular types of representations, such as the so-called Venus figurines, from Siberia to the Pyrenees (GaudzinskiWindheuer and Jöris 2015). The same phenomenon has been documented in parietal art in the whole of Western Europe, from Italy to Portugal (Petrognani and Robert 2019). Indeed, Cantabrian Spain participates fully in this abundant parietal artistic production and shares graphic resources at an interregional level (Garate et al. 2020). In contrast, figurative portable art is much scarcer and, for example, Venus figurines are unknown in the Cantabrian region. Figurative art on portable objects would not develop significantly until the Lower Magdalenian (Corchón 2004), and in fact, it did not reach the importance of proximate regions, like the Pyrenees or Dordogne, at any time in the Upper Paleolithic.

\section{Conclusions}

The results of the present study, obtained by the microscopic analysis of the objects, support a reappraisal of the emergence of portable graphic activity in Cantabrian Spain. In the Middle Paleolithic, the scarce evidence that can be considered graphic production is in line with other parts of the world and seems to confirm that this evidence is limited to more or less parallel marks, almost always on non-functional osseous objects. The characteristics of the incisions show that they were made in short operational sequences, with lines of similar or identical morphology, suggesting the use of the same tool in a homogeneous series of actions. However, this image of homogeneity is due to the simplicity of this type of production, since no recurrences allowing the determination of graphic analogies can be observed in the type of incisions, in their numbers, or in the type of objects.

For the Upper Paleolithic, this study has shown that the production of true decorated objects did not begin in the Cantabrian region until the Gravettian, when we find representations unconnected with functional processes on both osseous and lithic objects, and also the first figurative motifs that show significant parallelisms with parietal representations. The Aurignacian evidence is doubtful in general, especially the engravings on osseous objects, as in most cases these are taphonomic marks or found on remains with serious issues as regards their stratigraphic attribution. Only a few cases of groups of lines and non-figurative marks can be definitely assigned to this period.

This seems to support other forms of evidence, such as parietal art and the archaeological record. The scarce and heterogeneous Aurignacian artistic production is unevenly distributed in the region, and while the record increases in the Gravettian, it remains limited.

Supplementary Information The online version contains supplementary material available at https://doi.org/10.1007/s12520-021-01488-w.

Acknowledgements The authors would like to thank the responsible and curators of the Museo de Prehistoria y Arqueología de Cantabria (MUPAC) for their help in locating the pieces involved in the study. The authors thank M. Cueto for identifying the Morín piece (MO5) as a fish bone.

Funding Open Access funding provided thanks to the CRUE-CSIC agreement with Springer Nature. The study presented in this paper was funded by the research project of the Spanish Science Ministry "Learning and developing artistic skills in anatomically modern humans: a multidisciplinary approach" HAR2017-87739-P, led by Olivia Rivero.

Data availability Not applicable.

Code availability Not applicable.

\section{Declarations}

Ethics approval Not applicable.

Conflict of interest The authors declare no competing interests.

Open Access This article is licensed under a Creative Commons Attribution 4.0 International License, which permits use, sharing, adaptation, distribution and reproduction in any medium or format, as long as you give appropriate credit to the original author(s) and the source, provide a link to the Creative Commons licence, and indicate if changes were made. The images or other third party material in this article are included in the article's Creative Commons licence, unless indicated otherwise in a credit line to the material. If material is not included in the article's Creative Commons licence and your intended use is not permitted by statutory regulation or exceeds the permitted use, you will need to obtain permission directly from the copyright holder. To view a copy of this licence, visit http://creativecommons.org/licenses/by/4.0/. 


\section{References}

Abaunza A (2015) Los inicios de la expresión gráfica en el Pirineo occidental y la Cornisa Cantábrica: bases cronológicas a partir de soportes mobiliares. Estudios De Cuaternario 5:3-25

Abril López D (2012) La aplicación de análisis zooarqueológicos multivariables, espaciales y cuantitativos para la explicación de las relaciones sociales. Tesis Doctoral. Universidad de Huelva, Huelva

Aguirre Ruiz De Gopegui M, González Sainz C (2011) Placa con grabado figurativo del Gravetiense de Antoliñakokoba (Gautegiz-Arteaga, Bizkaia). Implicaciones en la caracterización de las primeras etapas de la actividad gráfica en la región Cantábrica. Kobie 30: 43-62. Bizkaiko Foru Aldunia-Diputación Foral de Bizkaia

Alcántara V, Barba E, Barral JM, Crespo AB, Eiriz AI, Falquina A, Herrero S, Ibarra A, Megías M, Pérez M, Pérez V, Rolland J, Yravedra J, Vidal A, Domínguez Rodrigo M (2006) Determinación de procesos de fractura sobre huesos frescos: un sistema de análisis de los ángulos de los planos de fracturación como discriminador de agentes bióticos. Trab Prehist 63(1):37-45

Álvarez Fernández E (2006) Los objetos de adorno-colgantes del Paleolítico Superior y del Mesolítico en la Cornisa Cantábrica y en el valle del Ebro: una visión europea. Tesis doctoral. Universidad de Salamanca, Salamanca

Ambert P, Guendon JL, Galant P, Quinif Y, Gruneisen A, Colomer A, Dainat D, Beaumes D, Requirand C (2005) Attribution des gravures paléolithiques de la grotte d'Aldène (Cesseras, Hérault) à l'Aurignacien par la datation des remplissages géologiques. CR Palevol 4(3):275-284

Andrews P, Whybrow P (2005) Taphonomic Observations on a Camel Skeleton in a Desert Environment in Abu Dhabi. Palaeontologia Electronica 8 (1)

Aranzadi T, Barandiarán JM, Eguren E (1925) Exploraciones de la caverna de Santimamiñe (Basondo: Cortézubi). $1^{a}$ Memoria Figuras rupestres. Reeditado en Barandiaran, J.M. 1976. Obras Completas, Tomo IX, 11-89

Arias Cabal P, Ontañón Peredo R (eds.) (2004) La materia del lenguaje prehistórico: El arte mueble paleolítico de Cantabria en su contexto. ( $2^{\mathrm{a}}$ ed.). Ministerio de Cultura, Instituto Internacional de Investigaciones Prehistóricas de Cantabria, Gobierno de Cantabria, Santander

Arrizabalaga A, Álvarez-Fernández E, Iriarte-Chiapusso MJ (2011) Spondylus sp. at Lezetxiki Cave (Basque Country, Spain): first evidence of its use in symbolic behaviour during the Aurignacian in Europe. In: Infantidis F, Nikolaidou M (eds) Spondylus in prehistory: new data and approaches - contributions to the archaeology of shell technologies. B.A.R. International Series S2216. BAR International Series, Oxford, 11-16. https://doi. org/10.13140/2.1.4711.7601

Aubert M, Brumm A, Huntley J (2018) Early dates for 'Neanderthal cave art' may be wrong. J Hum Evol 125:215-217

Aujoulat N, Geneste J, Archambeau C, Dellud M, Duday H, Gambier D (2002) La grotte ornée de Cussac - Le Buisson-de-Cadouin (Dordogne): premières observations. Bulletin De La Société Préhistorique Française 99(1):129-137

Azéma M, Gély B, Bourrillon R, Galant P (2012) The Palaeolithic art of La Baume Latrone (France, Gard): new dating elements. International Newsletter on Rock Art 64:6-12

Azéma M, Gely B, Prudhomme F, Societe AD, Atmd, (2010) Relevé 3D de gravures fines paléolithiques dans l'abri du Colombier (gorges de l'Ardèche). In Situ 13:1-15

Bahn PG (2016) Images of the Ice Age. Oxford University Press, Oxford
Balbín-Behrmann R, Alcolea-González JJ, Alcaraz-Castaño M (2017) The Palaeolithic art of Tito Bustillo cave (Asturias, Spain) in its archaeological context. Quatern Int 430:81-96

Balzeau A, Turq A, Talamo S, Daujeard C, Guérin G, Welker F, Crevecoeur I, Fewlass H, Hublin JJ, Lahaye C, Maureille B, Meyer M, Schwab C, Gómez-Olivencia A (2020) Pluridisciplinary evidence for burial for the La Ferrassie 8 Neandertal child. Sci Rep 10:21230. https://doi.org/10.1038/ s41598-020-77611-z

Barandiarán I (1971) Bramaderas en el Paleolítico Superior peninsular. Pyrenae 5:1-33

Barandiarán Maestu I (1972) Arte mueble del paleolítico cantábrico. Departamento de Prehistoria y Arqueología e Historia de la Antigüedad de la Universidad de Zaragoza, Zaragoza

Barandiarán Maestu I (1973) Arte Mueble del Paleolítico Cantábrico. Monografías Arqueológicas XIV, Zaragoza

Barandiarán Maestu I (1980) Industria ósea. In: González Echegaray $\mathrm{J}$ [et al.] El yacimiento de la cueva de El Pendo. Excavaciones 1953-57. Bibliotheca Praehistorica Hispana, Madrid, Vol. XVII, pp. 151-191

Barrière C (1976) L'art pariétal de la grotte de Gargas. BAR International Series 14, Mémoire de l'Institut d'Art Préhistorique de Toulouse, Oxford

Beaune SA de (2000) Pour une archéologie du geste. Broyer, moudre, piler, des premiers chasseurs aux premiers agriculteurs. CNRS, Paris

Beaune SA de (2017) Le matériel lithique non taillé de la grotte d'Isturitz issu des fouilles Passemard et Saint-Périer. In: Normand Ch, Cattellain P (eds) La grotte d'Isturitz. Fouilles anciennes et récentes. Actes de la table ronde du cinquantenaire du classement comme Monument Historique des grottes d'Isturitz et d'Oxocelhaya, 25-34. Cedarc, Treignes. Artefacts 13

Bednarik RG (2006) The Middle Palaeolithic engravings from Oldisleben, Germany. Anthropologie 44:113-121

Bednarik RG (2012) U-Th analysis and rock art: a response to Pike et al. Rock Art Research: The Journal of the Australian Rock Art Research Association (AURA) 29 (2):244-246

Behrensmeyer A (1978) Taphonomic and ecologic information from bone weathering. Paleobiology 4(2):150-162

Behrensmeyer AK, Kidwell SM (1985) Taphonomy's contributions to paleobiology. Paleobiology 11:105-119

Bello SM, Parfitt SA, Stringer CB (2009) Quantitative micromorphological analyses of cut marks produced by ancient and modern handaxes. J Archaeol Sci 36:1869e1880

Blasco R, Rosell J, Fernández Peris J, Cáceres I, Vergès JM (2008) A new element of trampling: an experimental application on the Level XII faunal record of Bolomor Cave (Valencia, Spain). J Archaeol Sci 35:1605-1618

Breuil H, Obermaier H (1912) Les premiers travaux de l'Institut de Paléontologie Humaine. L'anthropologie 23:1-27

Broglio A, Dalmeri G (Eds) (2005) Pitture paleolitiche nelle prealpi veneti. Grotta di Fumane e Riparo Dalmeri, Memoria des museo civica si storia naturale di Verona 2. Sezione scienze dell'uomo, Verona

Broglio A, De Stefani M, Gurioli F, Peresani M (2006) Les peintures aurignaciennes de la grotte de Fumane (Monts Lessini, Préalpes de la Vénétie). International Newsletter on Rock Art 44:1-8

Broglio A, Giachi G, Gurioli F, Pallecchi P (2007) Les peintures aurignaciennes de la Grotta di Fumane (Italie). Die aurignacienzeitlichen Malereien aus der Grotta die Fumane (Italien), in: Floss, H., Rouquerol, N. (Eds.), Les Chemins de l'art Aurignacien En Europe. Das Aurignacien Und Die Anfänge Der Kunst in Europa. Colloque International, Internationale Fachtagung, Aurignac, 16-18 Septembre 2005, Editions Musée-Forum Aurignac. Aurignac, $157-170$ 
Buikstra JE, Swegle M (1989) Bone modifications due to burning: experimental evidence. In Bonnichsen R y Sorg MH (Eds) Bone modifications. Center for the Study of the First Americans - University of Maine. Maine: 247-258

Cabrera V, Maillo JM, Lloret M, Bernaldo De Quirós F (2001) La transition vers le Paléolithique Supérieur dans la grotte du Castillo (Cantabrie, Espagne): la couche 18. L'anthropologie 105:505-532

Cabrera V, Bernaldo De Quirós F, Maíllo J M, Pike-Tay A, Garralda $M^{a} D$ (2005) Excavaciones en el Castillo: veinte años de reflexiones. In: Montes R, Lasheras J A (eds) Actas de la reunión científica Neandertales cantábricos, estado de la cuestión. Monografías 20, Museo de Altamira, Santander, 505-526

Cabrera V, Lloret M, Bernaldo De Quirós F (1996) Materias primas y formas líticas del Auriñaciense Arcaico de la Cueva del Castillo. Puente Viesgo, Cantabria Espacio, Tiempo y Forma, I 9:141-158

Cáceres I, Bennàssar M, Huguet R, Rosell J, Saladié P, Allué E, Solé A, Blasco R, Campeny G, Esteban-Nadal M, Fernández-Laso C, Gabuccio MJ, Ibáñez N, Martín P, Muñoz L, RodríguezHidalgo A (2012) Taphonomy of Level J of Abric Romaní. In: Carbonell i Roura E. (eds) High Resolution Archaeology and Neanderthal Behavior. Vertebrate Paleobiology and Paleoanthropology. Springer, Dordrecht, 159-185. https://doi.org/10.1007/ 978-94-007-3922-2_6

Cain CR (2005) Using burned animal bone to look at Middle Stone Age occupation and behavior. J Archaeol Sci 32:873-884

Capitan L, Peyrony D (1921) Les origines de l'art à l'Aurignacien moyen: nouvelles découvertes à La Ferrasie. Revue Anthropologique 31:92-112

Carballo J, Larin B (1933) Exploración en la gruta de "El Pendo"(Santander): Memoria. Junta Superior de Excavaciones y Antigüedades, Madrid

Caron F, d'Errico F, Del Moral P, Santos F, Zilhão J (2011) The reality of Neandertal symbolic behavior at the Grotte du Renne, Arcysur-Cure, France. PLoS ONE 6: e21545.

Chaix L, Méniel P (2005) Manual de Arqueozoología. Editorial Ariel S.A, Barcelona

Chalmin E (2003) Caractérisation des Oxydes de Manganèse et Usage des Pigments noirs au Paléolithique Supérieur. Thèse de Doctorat, Université de Marne-la-Vallée, France

Chiotti L, Delluc B, Delluc G (2007) Art et parure aurignaciens de l'abri Pataud (Les Eyzies-de-Tayac, Dordogne, France) dans le contexte aurignacien du Périgord. In : Floss H, Rouquerol $\mathrm{N}$ (dir) Les chemins de l'art aurignacien en Europe. Colloque International Aurignac 2005, Musée Forum Aurignac, cahier 4, Toulouse, pp. 171-188

Clottes C, Courtin J, Vanrell L (2005) Cosquer redécouvert. Seuil, Paris Conard NJ (2003) Palaeolithic ivory sculptures from southwestern Germany and the origins of figurative art. Nature 426:830-832

Conard NJ, Bolus M (2003) Radiocarbon dating the appearance of modern humans and timing of cultural innovations in Europe: new results and new challenges. J Hum Evol 44:331-371. https:// doi.org/10.1016/S0047-2484(02)00202-6

Corchón Mª (1986) El Arte Mueble Paleolítico Cantábrico: contexto y análisis interno. Monografía Centro de Investigación y Museo de Altamira 16, Madrid

Corchón $\mathrm{M}^{\mathrm{a}} \mathrm{S}$ (2004) El arte mueble Paleolítico en la cornisa cantábrica y su prolongación en el epipaleolítico. In: Fano Martínez JA (coord) Las Sociedades del Paleolítico en la Región Cantábrica. Kobie. (Serie Anejos), Bilbao, No 8: 425-475

Costamagno S, Soulier MC, Val A, Chong S (2019) Le référentiel de stries de boucherie. Palethnologie 10:195-291

Courtenay LA, Yravedra J, Maté-González MA, Aramendi J, GonzálezAguilera D (2019) 3D análysis of cut marks using a new geometric morphometric methodological approach. Archaeol Anthropol Sci 11:651-665
Crémades M, Laville H, Sirakov N, Kozlowski JK (1995) Une pierre gravée de 50000 ans B.P. dans les Balkans. Paléo 7:201-209. https://doi.org/10.3406/pal.1995.1215

D’Errico F (1994) L'Art gravé azilien. De la technique à la signification. Gallia Préhistoire, supplément XXXI. Eds. du CNRS, Paris

D'Errico F, Stringer CB (2011) Evolution, revolution or saltation scenario for the emergence of modern cultures? Philosophical Transactions of the Royal Society B Biological Sciences 366:1060-1069

D’Errico F, Vanhaeren M (1999) Les méthodes d'analyse de l'art mobilier paléolithique. Anthropologie Et Préhistoire 110:31-46

D'Errico F, Zilhao J, Julien M, Baffier D, Pelegrin J, Conrad NJ, Demars PY, Hublin JJ, Mellars P, Mussi M, Svoboda J, Taborin Y, Toscano LGV, White R (1998) Neanderthal acculturation in Western Europe?: a critical review of the evidence and its interpretation [and comments and reply]. Curr Anthropol 39:S1-S44

D'Errico F, Henshilwood CS, Nilssen P (2001) An engraved bone fragment from ca. 75 Kya Middle Stone Age levels at Blombos Cave, South Africa: implications for the origin of symbolism. Antiquity 75:309-318

De Juana S, Galán AB, Domínguez-Rodrigo M (2010) Taphonomic identification of cut marks made with lithic handaxes: an experimental study. J Archaeol Sci 37:1841e1850

De las Heras C, Lasheras J A, Arrizabalaga A, De la Rasilla M (2013) Pensando el Gravetiense: nuevos datos para la Región Cantábrica en su contexto peninsular y pirenaico. Monografías del Museo y Centro de Investigación de Altamira 26, Ministerio de Educación y Cultura, Madrid

Domingo I, Villaverde V, López-Montalvo E, Lerma JL, Cabrelles M (2013) Latest developments in rock art recording: towards an integral documentation of Levantine rock art sites combining 2D and 3D recording techniques. J Archaeol Sci 40(4):1879-1889

Domínguez-Rodrigo M, De Juana S, Galán AB, Rodríguez M (2009) A new protocol to differentiate trampling marks from butchery cut marks. J Archaeol Sci 36:2643-2654

Dutkiewicz E (2021) Zeichen. Markierungen, Muster und Symbole im Schwäbischen Aurignacien, Tübinger Monographien zur Urgeschichte. Kerns Verlag, Tübingen. Dutkiewicz, E., Wolf, S., Floss, H., Conard, N.J., 2018. Les objets en ivoire du Jura souabe. Anthropologie 122:447-468

Dutkiewicz E, Wolf S, Floss H, Conard NJ (2018) Les objets en ivoire du Jura souabe. L'Anthropologie 122:447-468

Dutkiewicz E, Russo G, Lee S, Bentz C (2020) SignBase, a collection of geometric signs on mobile objects in the Paleolithic. Scientific Data 7:364

Efremov IA (1940) Taphonomy: a new branch of paleontology. Pan Am Geol 74(2):81-93

Egeland CP, Welch KR, Nicholson CM (2014) Experimental determinations of cutmark orientation and the reconstruction of prehistoric butchery behavior. J Archaeol Sci 49:126-133

Fernández Jalvo Y, Cáceres I, Marín Monfort D (2013) Tafonomía. In García Díez M, Zapata I (Eds.) Métodos y técnicas de análisis y estudio en arqueología prehistórica: de lo técnico a la reconstrucción de los grupos humanos. UPV, Servicio Editorial: 367-408

Feruglio V, Dutailly B, Ballade M, Bourdier C, Ferrier C, Konik S, Lacanette-Puyo D, Mora P, Vergnieux R, Jaubert J (2013) Un outil de relevés 3D partagé en ligne: premières applications pour l'art et la taphonomie des parois ornées de la grotte de Cussac (ArTaPOC/programme LaScArBx) In Vergnieux R, Delevoie C (eds) Virtual Retrospect, Actes de colloque de Pessac, 27-29 novembre 2013, pp. 49-54

Finlayson C, Brown K, Blasco R, Rosell J, Negro JJ, Bortolotti GR, Finlayson G, Sánchez Marco A, Giles Pacheco F, Rodríguez Vidal J, Carrión JS, Fa DA, Rodríguez Llanes JM (2012) Birds 
of a feather: Neanderthal exploitation of raptors and corvids. PLOS ONE 7

Fortea J (1995) Abrigo de la Viña. Informe y primera valoración de las campañas 1991-1994. In: Excavaciones Arqueológicas en Asturias 1991-1994. Consejería de Educación y Cultura, Principado de Asturias, Oviedo, pp. 19-32

Fritz C (1999) La gravure dans l'art mobilier magdalénien, du geste à la représentation. Eds. de la Maison des Sciences de l'Homme, Paris

Galán AB, Domínguez-Rodrigo M (2013) Testing the efficiency of simple flakes, retouched flakes and small handaxes during butchery. Archaeometry 56(6):1054-1074

Garate D (2010) Las ciervas punteadas en las cuevas del paleolítico: una expresión pictórica propia de la cornisa cantábrica. Munibe, Aranzadi Zientzia Elkartea, Donostia

Garate D, Rios-Garaizar J (2011) Una plaqueta grabada procedente del nivel auriñaciense evolucionado de la cueva de Aitzbitarte III, pp. 376-384. In: Altuna J, Mariezkurrena K, Rios J (Eds) Ocupaciones humanas en Aitzbitarte III (País Vasco). colección de Patrimonio Cultural Vasco, 5

Garate-Maidagan D, Rivero Vilá O, Rios-Garaizar J (2015) Evaluating Aurignacian art in Iberia... if it really exist. P@lethnology 7: 236-255

Garate D, Tapia J, Rivero O, Álvarez I, Abendaño V, Aranburu A, Arriolabengoa M, Bodego A, Calvo JI, Garcia-Garcia E, Hermoso de Mendoza A, Ibarra F, Iriarte E, Legarrea J, del Val M, Agirre J (2017) Alkerdi 2: a new Gravetian rock art cave in the Western Pyrenees. International Newsletteron Rock Art 80:10-12

Garate D, Rivero O, Rios-Garaizar J, Arriolabengoa M, Intxaurbe I, Salazar S (2020) Redefining shared symbolic networks during the Gravettian in Western Europe: new data from the rock art findings in Aitzbitarte caves (Northern Spain). PLOS ONE 15:e0240481

García-Díez M, Arrizabalaga Valbuena A (2000) Soporte lítico con decoración lineal en el yacimiento de Labeko Koba (Arrasate, País Vasco). Munibe Antropologia-Arkeologia 52:377-383

García-Díez M, Ochoa B (2012) Caracterización del grafismo mueble figurativo gravetiense en la península ibérica. In: De Las Heras C, Lasheras J A, Arrizabalaga A, Rasilla M (eds) Pensando el Gravetiense: nuevos datos para la región cantábrica en su contexto peninsular y pirenaico. Museo Nacional y centro de investigación de Altamira (Monografía 23). Ministerio de Educación, Cultura y Deporte. Madrid, pp. 604-615

García-Díez M, Hoffmann DL, Zilhão J, De Las HC, Lasheras JA, Montes R, Pike AW (2013a) Uranium series dating reveals a long sequence of rock art at Altamira Cave (Santillana del Mar, Cantabria). J Archaeol Sci 40(11):4098-4106

García-Díez M, Ochoa Fraile B, Barandiarán Maestu I (2013) Neanderthal graphic behaviour. The pecked pebble from Axlor Rock shelter (Northern Spain). J Anthropol Res 69(3):397-410

Gaudzinski-Windheuer S, Jöris O (2015) Contextualising the female image - symbols for common ideas and communal identity in Upper Palaeolithic societies. In: Cowrd F, Hosfield R, Pope M, Wenban-Smith F (eds) Settlement, society, and cognition in human evolution. Cambridge University Press, Cambridge, Landscapes in mind, pp 288-314

Gómez-Olivencia A, Sala N, Núñez-Lahuerta C, Sanchis A, Arlegi M, Rios-Garaizar J (2018) First data of Neandertal bird and carnivore exploitation in the Cantabrian Region (Axlor; Barandiaran excavations; Dima, Biscay, Northern Iberian Peninsula). Sci Rep 8:10551. https://doi.org/10.1038/s41598-018-28377-y

González-Aguilera D, Muñoz-Nieto A, Gómez-Lahoz J, HerreroPascual J, Gutiérrez-Alonso G (2009) 3D digital surveying and modelling of cave geometry: application to paleolithic rock art. Sensors 9(2):1108-1127

González Echegaray J (1988) Decorative patterns in the Mousterian of Cueva Morín. In: M Otte\& O Bar-Yosef (eds) L'homme de
Néandertal. (Vol. 5: La pensée). Université de Liège, Liège, $37-42$

González Echegaray J, Barandiarán I (1981) El Paleolítico Superior de la cueva del Rascaño (Santander). Centro de Investigación y Museo de Altamira, monografía 3, Santander

González Echegaray J, Freeman LG (1971) Cueva Morín. Santander, Publicaciones del Patronato de las cuevas prehistóricas de la provincia de Santander, VI

González Echegaray J, Freeman L G (1973) Los enterramientos paleolíticos de Cueva Morín (Santander). Patronato de las Cuevas Prehistóricas, Santander

González Echegaray J, Freeman LG (1976) El hombre de Morín: un enterramiento de hace 29000 años. Historia 16(4):63-68

González Echegaray J, Freeman L G (1978) Vida y muerte en cueva Morin. Institución Cultural de Cantabria. Santander

González Echegaray J, García Guinea MA, Begines A (1966) Cueva del Otero. Excavaciones Arqueológicas en España, 53. Ministerio de Educación, Madrid

González Echegaray J, Freeman L G, Butzer K W (1971) Cueva Morín: Excavaciones 1966-1968. Patronato de las Cuevas Prehistóricas, Santander

González Sainz C, García Díez M, San Miguel Llamosas C, Aja Santisteban G, Eguizabal Torre J (2003) Nuevos materiales arqueológicos de la cueva de "El Arco B" (Ramales de la Victoria, Cantabria). Veleia: Revista de prehistoria, historia antigua, arqueología y filología clásicas 20: 123-141

González Sainz C, Ruiz Redondo A, Garate D, Iriarte E (2013) Not only Chauvet: dating Aurignacian rock art in Altxerri B Cave (northern Spain). J Hum Evol 65(4):457-464

Grosman L, Karasik A, Harush O, Smilansky U (2014) Archaeology in three dimensions: computer-based methods in archaeological research. J East Mediterr Archaeol Herit Stud 2(1):48-64

Gutiérrez-Zugasti I, Cuenca-Solana D, Rasines del Río P, Muñoz E, Santamaría S, Morlote JM (2013) The role of shellfish in hunter-gatherer societies during the Early Upper Palaeolithic: a view from El Cuco rockshelter, northern Spain. J Anthropol Archaeol 32(2):242-256

Gutiérrez-Zugasti I, Rios-Garaizar J, Marín-Arroyo AB, Rasines del Río P, Maroto J, Jones JR, Bailey GN, Richards MP (2018) A chrono-cultural reassessment of the levels VI-XIV from El Cuco rock-shelter: a new sequence for the Late Middle Paleolithic in the Cantabrian region (northern Iberia). Quatern Int 474:44-55. https://doi.org/10.1016/j.quaint.2017.06.059

Henshilwood CS, d'Errico F, van Niekerk KL, Dayet L, Queffelec A, Pollarolo L (2018) An abstract drawing from the 73000-yearold levels at Blombos Cave, South Africa. Nature 562:115-118

Higham T, Basell L, Jacobi R, Wood R, Ramsey CB, Conard NJ (2012) Testing models for the beginnings of the Aurignacian and the advent of figurative art and music: the radiocarbon chronology of Geißenklösterle. J Hum Evol 62:664-676. https://doi.org/10.1016/j.jhevol.2012.03.003

Higham T, Douka K, Wood R et al (2014) The timing and spatiotemporal patterning of Neanderthal disappearance. Nature 512:306-309. https://doi.org/10.1038/nature13621

Hoffmann DL, Standish CD, García-Díez M, Pettitt PB, Milton JA, Zilhão J et al (2018a) U-Th dating of carbonate crusts reveals Neandertal origin of Iberian cave art. Science 359(6378):912-915

Hoffmann DL, Standish CD, García-Díez M, Pettitt PB, Milton JA, Zilhão J et al (2018b) Response to Comment on "U-Th dating of carbonate crusts reveals Neandertal origin of Iberian cave art". Science 362 (6411)

Hoffmann DL, Standish CD, Pike AW, García-Díez M, Pettitt PB, Angelucci DE et al (2018c) Dates for Neanderthal art and symbolic behaviour are reliable. Nature Ecology \& Evolution 2(7): 1044 
Hoffmann DL, Standish CD, García-Díez M, Pettitt PB, Milton JA, Cantalejo-Duarte P, Collado H, De Balbín R, Lorblanchet M, Weniger GC, Pike A (2019) Response to Aubert et al'.s reply 'Early dates for "Neanderthal cave art" may be wrong' [J. Hum. Evol. 125 (2018), 215-217]. J Hum Evol 135:1-5

Kozlowski JK (1992) The Balkans in the Middle Paleolithic and Upper Paleolithic: the gateway to Europe or a cul-de-sac. Proc Prehist Soc 58:1-20

Lejeune M (2007) Le Trou Magrite et l'art mobilier aurignacien en Belgique: synthèse et problèmes. In : Floss H, Rouquerol N (dir) Les chemins de l'art aurignacien en Europe. Colloque International Aurignac 2005, Musée Forum Aurignac, cahier 4, Toulouse, pp. 131-144

López-González F, Grandal-d'Anglade A, Vidal-Romaní JR (2006) Deciphering bone depositional sequences in caves through the study of manganese coatings. J Archaeol Sci 33:707-717

López Quintana JC (2011) La cueva de Santimamiñe: revisión y actualización (2004-2006). Kobie. Bizkaiko Arkeologi Indusketak 1

Lyman RL (2010) What taphonomy is, what is isn't and why taphonomy should care about the difference. J Taphon 8(1):1-16

Majkić A, d'Errico F, Milošević S, Mihailović D, Dimitrijević V (2017) Sequential incisions on a cave bear bone from the Middle Paleolithic of Pešturina Cave, Serbia. J Archaeol Method Theory 25:69-116

Marín-Arroyo AB, Landete-Ruiz MD, Seva-Román R, Lewis MD (2014) Manganese coating of the Tabun faunal assemblage: implications for modern human behaviour in the Levantine Middle Palaeolithic. Quatern Int 330:10-18

Marín-Arroyo AB, Rios-Garaizar J, Straus LG, Jones JR, de la Rasilla $\mathrm{M}$ et al (2018) Correction: Chronological reassessment of the Middle to Upper Paleolithic transition and Early Upper Paleolithic cultures in Cantabrian Spain. PLoS ONE 13(6):e0199954. https://doi.org/10.1371/journal.pone.0199954

Maroto J, Vaquero M, Arrizabalaga A, Baena J, Baquedano E, Jordá Pardo JF, Julià Brugués R, Montes R, Van Der Plicht J, Rasines P, Wood RE (2012) Current issues in late Middle Palaeolithic chronology: new assessments from Northern Iberia. Quatern Int 247:15-25

Maté González MA, Yravedra J, González-Aguilera D, PalomequeGonzález JF, Domínguez-Rodrigo M (2015) Micro-photogrammetric characterization of cut marks on bones. J Archaeol Sci 62:128-142

Maté-González MÁ, Palomeque-González JF, Yravedra J et al (2018) Micro-photogrammetric and morphometric differentiation of cut marks on bones using metal knives, quartzite, and flint flakes. Archaeol Anthropol Sci 10:805-816. https://doi.org/10.1007/ s12520-016-0401-5

Mateo Pellitero AM (2015) La Motilla del Azuer: estudio zooarqueológico y tafonómico de restos faunísticos. Universidad de Granada, Trabajo de Fin de Máster

Montes R, Sanguino J, Martín P, Gómez AJ, Morcillo C (2005) La secuencia estratigráfica de la Cueva del Pendo (Escobedo de Camargo, Cantabria): Problemas geoarqueológicos de un referente cronocultural. In: Santonja M, Pérez-González A, Machado MJ (eds) Geoarqueología y Patrimonio En La Península Ibérica y En El Entorno Mediterráneo. ADEMA, pp. 139-159

Montes Barquín R, Sanguino González J (dir) (2021) La cueva de Covalejos (Velo de Piélagos, Cantabria). Ocupaciones neandertales y sapiens en la cuenca baja del río Pas. Actuaciones arqueológicas 1997-1999 y 2002. Monografías del Museo de Prehistoria y Arqueología de Cantabria, 2021

Moreno García M (2013) Arqueozoología. In: García-Díez M, Zapata L (eds) Métodos y técnicas de análisis y estudio en arqueología prehistórica: de lo técnico a la reconstrucción de los grupos humanos. UPV, Servicio Editorial, pp. 346-366
Mozota Holgueras M (2012) El hueso como materia prima: el utillaje óseo del final del musteriense en el sector central del norte de la península ibérica. Universidad de Cantabria, Tesis doctoral

Mozota Holgueras M (2014) Los útiles óseos "poco elaborados" en el Paleolítico inferior y medio y su continuidad en el Paleolítico superior. Una Revisión Historiográfica Complutum 25:17-33

Mujika JA (2000) La industria ósea del Paleolítico Superior Inicial de Labeko Koba (Arrasate, Basque Country). In: Arrizabalaga A, Altuna J (eds) Labeko Koba (País Vasco) Hienas y humanos en los albores del Paleolítico superior. Munibe 52: 355-376. Sociedad de Ciencias Aranzadi Zientzia Elkartea. Donostia- San Sebastián.

Muñoz E (1991) Excavaciones arqueológicas en la cueva del Ruso I. Avance Preliminar Arquenas 1:61-157

Normand C (2007) Les Aurignaciens de la grotte d'Isturitz (communes d'Isturitz et de Saint-Martin-d'Arberoue; Pyrénées-Atlantiques; France). In : Floss H, Rouquerol N (dir) Les chemins de 1'art aurignacien en Europe. Colloque International Aurignac 2005, Musée Forum Aurignac, cahier 4, Toulouse, 77-88

Obermaier H (1925) El Hombre Fósil. Museo Nacional de Ciencias Naturales, Madrid

Ortega I, Rios-Garaizar J, Garate Maidagan D, Arizaga J, Bourguignon L (2015) A naturalistic bird representation from the Aurignacian layer at the Cantalouette II open-air site in southwestern France and its relevance to the origins of figurative art in Europe. J Archaeol Sci Rep 4:201-209. https://doi.org/10.1016/j.jasrep. 2015.09.009

Pearce DG, Bonneau A (2018) Trouble on the dating scene. Nature Ecology \& Evolution 2(6):925-926

Peresani M, Fiore I, Gala M, Romandini M, Tagliacozzo A (2011) Late Neandertals and the intentional removal of feathers as evidenced from bird bone taphonomy at Fumane Cave 44 ky B.P., Italy. Proc Natl Acad Sci 108:3888-3893. https://doi.org/10.1073/ pnas. 1016212108

Petrognani S, Robert E (2019) Symbolic territories in pre-Magdalenian art? Quatern Int 503:210-220

Pike AWG, Hoffmann DL, García-Díez M, Pettitt PB, Alcolea J, De Balbín R, González-Sainz C, De Las HC, Lasheras JA, Montes R, Zilhão J (2012) U-series dating of Paleolithic art in 11 caves in Spain. Science 336(6087):1409-1413

Pike AW, Hoffmann DL, Pettitt PB, García-Díez M, Zilhao J (2017) Dating Palaeolithic cave art: why U-Th is the way to go. Quatern Int 432:41-49

Pineda A, Saladié P, Vergès JM, Huguet R, Cáceres I, Vallverdú J (2014) Trampling versus cut marks on chemically altered surfaces: an experimental approach and archaeological application at the Barranc de la Boella site (la Canonja, Tarragona, Spain). J Archaeol Sci 50:84-93

Pinto A, Grandal A (2019) Conflicting ${ }^{14} \mathrm{C}$ scenarios in the Sopeña cave (northern Iberia): dating the Middle-Upper Palaeolithic boundary by non-ultrafiltered versus ultrafiltered $A M S{ }^{14} \mathrm{C}$. Quatern Int 522:1-11

Plisson H, Zotkina LV (2015) From 2D to 3D at macro- and microscopic scale in rock art studies. Digital Applications in Archaeology and Cultural Heritage 2(2-3):102-119

Pons-Branchu E, Bourillon R, Conkey MW, Fontugne M, Fritz C, Garate D, Quiles A, Rivero O, Sauvet G, Tosello G, Valladas H, White R (2014) Uranium-series dating of carbonate formations overlying Palaeolithic art; interest and limitations. Bulletin De La Societe Prehistorique Française 111(2):211-224

Prévost M, Groman-Yaroslavski I, Crater Gershtein KM, Tejero JM, Zaidner Y (in press) Early evidence for symbolic behavior in the Levantine Middle Paleolithic: a $120 \mathrm{ka}$ old engraved aurochs bone shaft from the open-air site of Nesher Ramla, Israel. Quaternary International https://doi.org/10.1016/j. quaint.2021.01.002 
Quiles A, Valladas H, Bocherens H, Delqué-Kolic E, KaltneckervE, van der Plicht J, Delannoy JJ, Feruglio V, Fritz C, Monney J, Philippe M, Tosello G,Clottes J, Geneste JM (2016) A high-precision chronological model for the decorated Upper Paleolithic cave of Chauvet-Pont d'Arc, Ardèche, France. Proc Natl Acad Sci 113(17):4670-4675.

Rasines P, Maroto J, Muñoz-Fernández E, Morlote-Expósito JM, Castaños P, Castaños de la Fuente J, Santamaría-Santamaría S, Millán F (2021) A chrono-cultural reassessment of levels III-V from El Cuco rock-shelter: a new sequence for the late Middle Palaeolithic - early Upper Palaeolithic boundary in the Cantabrian region (northern Iberia) Comptes Rendus Palevol 20(18):315-343. https://doi.org/10.5852/cr-palevol2021v20a18

Richardson E, Grosman L, Smilansky U, Werman M (2013) Extracting scar and ridge features from 3D-scanned lithic artifacts. In: Sly T, Wheatley D et al (eds) Earl G. Archaeology in the Digital Era, Amsterdam University Press, pp 83-92

Rios-Garaizar J (2012) Industria lítica y sociedad en la Transición del Paleolítico Medio al Superior en torno al Golfo de Bizkaia. PUbliCan - Ediciones de la Universidad de Cantabria, Santander

Rios-Garaizar J (2017) A new chronological and technological synthesis for Late Middle Paleolithic of the Eastern Cantabrian Region. Quatern Int 433:50-63. https://doi.org/10.1016/j.quaint.2016.02. 020

Rios-Garaizar J, Garate D (2014) Actualisation de l'inventaire des pointes de type Isturitz de la région cantabrique. PALEO $25: 233-245$

Rios-Garaizar J, García-Moreno A (2015) Middle Paleolithic Mobility patterns and settlement system variability in the Eastern Cantabrian Region (Iberian Peninsula): a GIS-based resource patching model. In: Conard NJ, Delagnes A (eds) Settlement dynamics of the Middle Paleolithic and Middle Stone Age, vol 4. Kerns Verlag, Tübingen, pp 329-360

Rios-Garaizar J, López-Bultó O, Iriarte E, Pérez-Garrido C, Piqué R, Aranburu A, Iriarte-Chiapusso MJ, Ortega-Cordellat I, Bourguignon L, Garate D, Libano I (2018) A middle palaeolithic wooden digging stick from aranbaltza III. Spain Plos ONE 13:e0195044. https://doi.org/10.1371/journal.pone.0195044

Rios-Garaizar J, Maíllo-Fernández JM, Marín-Arroyo AB, Sánchez Carro MA, Salazar S, Medina-Alcaide MA, San Emeterio A, Martínez de Pinillos L, Garate D, Rivero O (2020) Revisiting Hornos de la Peña 100 years after. J Archaeol Sci Rep 31:102259. https://doi.org/10.1016/j.jasrep.2020.102259

Ríos Nuñez F (2017) Estudio de la industria ósea de la cueva de Aitzbitarte III (Zona Interior), in: Altuna, J., Mariezkurrena, K., Rios-Garaizar, J., San Emeterio, A. (Eds.), Aitzbitarte III (País Vasco). 26.000-13.000 BP (Zona Profunda de La Cueva). Eusko Jaurlaritzaren Argitalpen Zerbitzu Nagusia, Vitoria-Gasteiz, pp. $187-246$

Rivero O (2010) La movilidad de los grupos humanos en el Magdaleniense de la Región Cantábrica y los Pirineos: una visión a través del arte. Tesis doctoral. Universidad de Salamanca

Rivero O (2015) Art mobilier des chasseurs magdaléniens de la façade atlantique. Ed. ERAUL, 146, Liège

Rivero O (2017) Los recursos técnicos en el arte paleolítico: una aproximación desde las cadenas operativas. In Garate D (coord) Redescubriendo el arte parietal paleolítico. Últimas novedades sobre los métodos y las técnicas de investigación. Kobie (anejos) $16: 87-100$

Rivero O, Garate D (2014) L'art mobilier gravettien sur support lithique de la grotte d'Isturitz (Saint-Martin-d'Arberoue, PyrénéesAtlantiques, France): une collection redécouverte. PALEO Revue D'archéologie Préhistorique 25:247-276

Rivero O, Ruiz López JF, Salazar S, Garate D (2019) On the limits of $3 \mathrm{D}$ capture: a new method to approach the photogrammetric recording of palaeolithic thin incised engravings in Atxurra Cave (northern Spain). Digital Applications in Archaeology and Cultural Heritage 14

Rodríguez-Hidalgo A, Morales JI, Cebrià A, Courtenay LA, Fernández-Marchena JL, García-Argudo G, Marín J, Saladié P, Soto M, Tejero JM, Fullola JM (2019) The Châtelperronian Neanderthals of Cova Foradada (Calafell, Spain) used imperial eagle phalanges for symbolic purposes. Science Advances 5, eaax1984. https:// doi.org/10.1126/sciadv.aax1984

Rodríguez-Vidal J, d'Errico F, Pacheco FG, Blasco R, Rosell J, Jennings RP, Queffelec A, Finlayson G, Fa DA, Gutiérrez López JM, Carrión JS, Negro JJ, Finlayson S, Cáceres LM, Bernal MA, Fernández Jiménez S, Finlayson C (2014) A rock engraving made by Neanderthals in Gibraltar. Proc Natl Acad Sci 111:13301-13306. https://doi.org/10.1073/pnas.1411529111

San Juan C, Vercoutère C, Foucher P (2007) Parures et objets décorés aurignaciens de la grotte de Gargas (Hautes-Pyrénées, France). In : Floss H, Rouquerol N (dir) Les chemins de l'art aurignacien en Europe. Colloque International Aurignac 2005, Musée Forum Aurignac, cahier 4, Toulouse, 89-104

San Juan-Foucher C (2006) Industrie osseuse décorée du Gravettien des Pyrénées. Munibe Antropologia-Arkeologia 57(III):95-111

San Juan Foucher C, Vercoutère C (2013) Côtes. In: Mons L., Péan S., Pigeaud R., dir. Matière d'art. Représentations préhistoriques et supports osseux, relations et contraintes, Arles, Éd. Errance (Industrie de l'os préhistorique, cahier 13) : 107-142

Sánchez-Romero L, Benito-Calvo A, Marín-Arroyo AB, Agudo-Pérez L, Karampaglidis T, Rios-Garaizar J (2020) New insights for understanding spatial patterning and formation processes of the Neanderthal occupation in theAmalda I cave (Gipuzkoa, Spain). Sci Rep 10:8733. https://doi.org/10.1038/s41598-020-65364-8

Sanguino González J, Montes Barquín R (2005) Nuevos datos para el conocimiento del Paleolítico Medio en el centro de la Región Cantábrica: La Cueva de Covalejos. In: Montes R, Lasheras JA (eds) Actas de la reunión científica Neandertales cantábricos, estado de la cuestión. Monografías 20, Museo de Altamira, Santander, 489-504

Sauvet G, Bourrillon R, Conkey M, Fritz C, Garate D, Rivero O, Tosello G, White R (2017) Uranium-Thorium dating method and rock art. Quatern Int 432:86-92

Shaham D, Belfer-Cohen A, Rabinovich R, Goren-Inbar N (2019) A Mousterian engraved bone. Principles of perception in Middle Paleolithic art. Current Anthropology 60(5):708-716

Shipman P, Rose J (1983) Early hominid hunting, butchering and carcass-processing behaviors: approaches to the fossil record. J Anthropol Archaeol 2:57-98

Slimak L, Fietzke J, Geneste JM, Ontañón R (2018) Comment on "U-Th dating of carbonate crusts reveals Neandertal origin of Iberian cave art." Science 361(6408): 1371

Soressi M, d'Errico F (2007) Pigments, gravures, parures: les comportements symboliques controversés des Néandertaliens. Les Néandertaliens. Biologie et cultures. Paris, Éditions du CTHS: 297-309

Soulier MC, Costamagno S (2017) Let the cutmarks speak! Experimental butcheries to reconstruct carcass processing. J Archaeol Sci Rep 11:782-802

Svoboda J (1997) Symbolisme gravettien en Moravie. Espace, temps et formes. Bulletin De La Société Préhistorique De L'ariègePyrénées 52:87-104

Tejero JM, Bernaldo de Quirós F (2007-2008) Evidencias de trabajo en materias duras animales en el Auriñaciense de transición (unidad 18) de la cueva de "El Castillo" (Puente Viesgo, Cantabria). Veleia 24-25 (1): 415-424.

Tejero JM, Cacho C, Bernaldo De Quirós F (2008) Arte mueble en el Auriñaciense cantábrico. Nuevas aportaciones a la 
contextualización del frontal grabado de la cueva de Hornos de la Peña (San Felices de Buelna, Cantabria). Trabajos de Prehistoria, 65/1: 115-123

Utrilla P (1981) El Magdaleniense Inferior y Medio en la Costa Cantábrica. Centro de Investigación y Museo de Altamira, monografía 4, Madrid

Vanhaeren M, d'Errico F (2005) Grave goods from the Saint-Germainla-Rivière burial: evidence for social inequality in the Upper Palaeolithic. J Anthropol Archaeol 24(2):117-134. https://doi.org/ 10.1016/j.jaa.2005.01.001

White R (2007) Systems of personal ornamentation in the Early Upper Palaeolithic: methodological challenges and new observations. In: Rethinking the human revolution: new behavioural and biological perspectives on the origin and dispersal of modern humans. McDonald Institute for Archaeological Research: 287-302

White R, Mensan R, Bourrillon R, Cretin C, Higham T, Clark A, Sisk M, Tartar E, Gardere P, Pelegrin J, Valladas H, TisneratLaborde N, Sanoit (De) J, Chambellan, Chiotti L (2012) Context and dating of a newly discovered Aurignacian « vulvar » representation from Abri Castanet, France. Proc Natl Acad Sci 109(22):8450-8455

White R, Bosinsk GI, Bourrillon R, Clottes J, Conkey MW, CorchóN S, Cortés-Sánchez M, De La Rasilla M, Delluc B, Delluc G, Feruglio V, Floss H, Foucher P, Fritz C, Fuentes O, Garate D, González J, González-Morales M, González-Pumariega M, Groenen M., Jaubert J., Martinez-Aguirre, M.A., Medina Alcaide M.A., Moro O., Ontañón R., Paillet-Man-Estier E, Paillet E, Petrognani E, Pigeaud R, Pinçon G, Plassard F, Ripoll S, Rivero O, Robert E, Ruiz-Redondo A, Ruiz JF, San Juan-Foucher C, Sanchidrián JL, Sauvet G, Simón-Vallejo MD, Tosello G, Utrilla P, Vialou D, Willis MD (2020) Still no archaeological evidence that Neanderthals created Iberian cave art. Journal of Human Evolution 144. https://doi.org/10.1016/j.jhevol.2019.102640
Wolf S, Heckel C (2018) Ivory Ornaments of the Aurignacian in Western Europe: case studies from France and Germany. Anthropologie 122(3):348-373

Yravedra J (2006) Tafonomía aplicada a la Zooarqueología. Universidad Nacional de Educación a Distancia, Madrid

Yravedra J, Maté-González MÁ, Palomeque-González JF, Aramendi J, Estaca-Gómez V, San Juan Blazquez M, García Vargas E, Organista E, González-Aguilera D, Arriaza MC, Cobo-Sánchez L, Gidna A, Uribelarrea del Val U, Baquedano E, Mabulla A, Domínguez-Rodrigo M (2017) A new approachto raw material use in theexploitationof animal carcasses at BK (UpperBed II, Olduvai Gorge, Tanzania): a micro-photogrammetric and geometric morphometric analysis of cut marks. Boreas 46:860-873

Zilhâo J (2012) Personal ornaments and symbolism among the Neanderthals. Developments in Quaternary Science 16:35-49

Zilhâo J, D'Errico F (1999) The chronology and taphonomy of the earliest Aurignacien and its implications for the understanding of Neandertal extinction. J World Prehist 13(1):2-68

Zilhâo J, D'Errico F (2003) The chronology of the Aurignacian and Transitionaltechnocomplexes. Where do we stand? In: Zilhâo J, D'Errico F (eds) The Chronology of the Aurignacian and of the transitional technocomplexes. Dating, Stratigraphies, Cultural Implications. Symposium 6.1 of the XIVth Congress of the UISPP. University of Liège. Belgium. September 2-8. 2001. Trabalhos de Arqueologia 33. Instituto Portugues de Arqueología, pp. 313-349.

Zotkina LV, Miklashevich EA (2016) Traceological analysis of the minusinsk style petroglyphs at the Oglakhty VI rock art site (Khakasia). Vestnik NSU 15(5):31-43

Publisher's note Springer Nature remains neutral with regard to jurisdictional claims in published maps and institutional affiliations. 